\title{
A FIGURA DE ÁTILA, REI DOS HUNOS, NA HISTÓRIA DOS GODOS ESCRITA POR JORDANES
}

\author{
De origine actibusque Gerarum vel Getica (excertos)
}



JORDANES

GUSTAVO H. S. S. SARTIN (TRADUTOR)

Resumo: A história dos godos de Jordanes ou Getica - é a mais antiga das histórias restantes de um povo "bárbaro" pós-romano, mas o seu autor alega que ela é um resumo da história gótica escrita por Cassiodoro, que não atravessou a Idade Média. A obra original supostamente foi escrita na Italia durante a década de 520, quando Cassiodoro residia na corte dos reis ostrogodos, mas a de Jordanes foi escrita por volta de 550 em Constantinopolis. Cerca de um sexto da obra de Jordanes trata de eventos envolvendo Átila, rei dos hunos. O relato de Jordanes acerca das estripulias de Átila pode ser lido quase como uma peça literária independente, na qual o protagonista é o povo visigodo como um todo, com o rei dos hunos desempenhando o papel do antagonista malvado que rouba a cena, enquanto o general romano Aécio tem o papel de não muito mais do que um silencioso ajudante menor dos visigodos. No presente trabalho, traduzimos todos os excertos da Getica relativos a Átila e os analisamos a partir de alguns conceitos extraídos da Linguística Sistêmico-Funcional.

Palavras-chave: Antiguidade Tardia; historiografia; invasões bárbaras; visigodos; hunos
Abstract: The Gothic history of Jordanes or Getica - is the oldest extant history of a "barbaric" post-Roman people, but its author also alleges that it is an abridgement of the Gothic history written by Cassiodorus which didn't make it through the Middle Ages. The original work was supposedly written in Italy during the 520s, when Cassiodorus resided on the court of the Ostrogothic kings, but Jordanes' was written around 550 in Constantinople. About a sixth of Jordanes' work deals with events involving Attila, the king of the Huns. Jordanes' account of Attila's shenanigans reads almost like a single, stand-alone literary piece in which the protagonist is the Visigothic people as a whole, with the king of the Huns playing the part of the evil antagonist who steals the scene, while the Roman general Aetius serves as not much more than a silent sidekick to the Visigoths. In the present paper, I translate all the excerpts of the Getica related to Attila and analyse them with the help of some concepts extracted from Systemic Functional Linguistics.

Keywords: Late Antiquity; historiography; barbarian invasions; visigoths; huns 


\section{Contexto histórico}

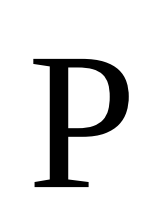

ublicada pelo godo Jordanes em Constantinopolis no ano de 551 ou 552, a Getica, também chamada De origine actibusque Getarum (Sobre as Origens e Feitos dos Godos), foi baseada em uma obra hoje perdida, escrita cerca de vinte anos antes por Cassiodoro Senador, um romano do sul da Italia que ocupava o cargo de magister officiorum ("mestre dos ofícios", uma espécie de primeiro-ministro) do reino dos ostrogodos. ${ }^{1}$ Em virtude do desaparecimento do texto de Cassiodoro, a mais antiga história de um povo "bárbaro" pós-romano hoje disponível é a escrita por Jordanes.

A despeito de ser frequentemente publicada de forma isolada em tempos modernos, a Getica é a terceira parte de uma obra maior. A primeira consiste em uma cronologia universal nos moldes cristãos, que termina com a ascensão de Augusto e o início do que seria o quinto e último império mundial. A segunda é uma história romana que vai do nascimento de Rômulo até o vigésimo quarto ano do reinado de Justiniano I, em 551. As duas primeiras partes formam De Summa Temporum uel Origine Actibusque Gentis Romanorum (O Ápice dos Tempos ou as Origens e Feitos dos Romanos) ou, simplesmente, Romana. A Getica, por sua vez, narra a trajetória dos godos desde tempos mitológicos na Scandza (região correspondente à Escandinávia atual, imaginada como sendo uma ilha) até 540, quando o rei ostrogodo Vitiges rendeu-se a Belisário, comandante militar do Império Romano do Oriente, em Ravenna. A primeira parte trata das origens e migrações dos godos, a segunda conta a história dos visigodos e a terceira, dos ostrogodos.

Átila, por vezes apelidado de “o flagelo de Deus” (flagelum Dei), ascendeu ao comando dos hunos em companhia do irmão, Bleda, em meados da década de 430. Juntos eles conduziram um exército multiétnico, que incluía homens de tribos submetidas, como a dos ostrogodos, em ataques sucessivos contra o terrítório do Império Romano do Oriente. Após tramar a morte do irmão, na década seguinte, Átila voltaria sua atenção para o ocidente, tornando-se protagonista do que pode ser considerada a última grande batalha do Império Romano do Ocidente, ocorrida no ano de 451 nos campos Cataláunicos (próximos a Châlons-en-Champagne, na França). Nela, um exército liderado por romanos e visigodos enfrentou as forças de Átila. O relato contido na Getica é a principal fonte a respeito dessa batalha. ${ }^{2}$

\footnotetext{
${ }^{1}$ A respeito das controvérsias historiográficas sobre a Getica, vide GOFFART (1988, pp.20-31).

2 Com exceção do parágrafo acerca de Átila, o texto das seções “Contexto histórico”, “Edição” e "Linguagem” é baseado no de outro trabalho nosso publicado na Scientia Traductionis (no. 11, 2012), no qual traduzimos a introdução geográfica da Getica. JORDANES; SARTIN, Gustavo H. S. S. Sobre a Origem e Feitos dos Godos. Scientia Traducionis, no. 11, pp. 330-359, 2012. PGET/UFSC.
} 


\section{Edição}

A Getica tem por editio princeps uma publicação de Konrad Peutinger em Augsburg, no ano de 1515, na qual era acompanhada pela história dos lombardos de Paulo Diácono. ${ }^{3}$ Utilizamos como texto-fonte a edição considerada canônica, publicada em 1882 por Theodor Mommsen como parte da coleção Monumenta Germaniae Historica, que contém a Romana e a Getica. ${ }^{4}$

\section{Linguagem}

O texto de Jordanes foi elaborado no que se convencionou chamar de “Latim tardio", expressão escrita de uma língua que, mesmo restrita por uma tradição literária que até certo ponto ainda se buscava preservar, mantinha-se viva. Distingue-se, nesse sentido, do chamado "Latim medieval”, perceptível claramente nos documentos produzidos a partir de meados do século VIII, que precisava ser aprendido como uma segunda língua mesmo pelos habitantes das áreas ditas "latinas".

Incorporando progressivamente elementos do chamado "Latim vulgar", termo que a um só tempo se refere à linguagem coloquial e à fala das camadas populares, o Latim tardio conservou a maioria dos aspectos sintáticos e morfológicos de seu antecessor "clássico" até por volta do ano 600, ponto a partir do qual exemplos de simplificações do antigo sistema de casos tornam-se cada vez mais frequentes no registro escrito, em um processo que, combinado com transformações no sistema fonético, resultou no surgimento das línguas românicas. ${ }^{5}$

Se, em nosso caso particular, levarmos em consideração, adicionalmente, que o autor não era etnicamente romano, que escreveu em Latim enquanto vivia em uma área predominantemente grega e que não teve qualquer formação em Retórica durante a juventude, ${ }^{6}$ perceberemos que foi inevitável, além de absolutamente natural, que ele tenha sido incapaz de escrever em uma linguagem idêntica à dos autores clássicos.

\section{Nossa tradução e a questão da avaliatividade}

De acordo com J. R. Martin e David Rose (2007, p. 7), a Linguística Sistêmico-Funcional reconhece os seguintes aspectos gerais do emprego social da linguagem: (1) a chamada "metafunção interpessoal” possibilita o estabelecimento de relações sociais; (2) a "metafunção ideacional”, a representação das experiências; (3) e, finalmente, a "metafunção textual” permite a organização textual de nossas relações sociais e experiências.

\footnotetext{
${ }^{3}$ Jornandes de rebus Gothorum. Paulus Diaconus Forojuliensis de Gestis Longobardorum. Edente Chuonradus Peutinger. Augustae Vindelicorum: Ioannes Miller, 1515.

${ }^{4}$ MOMMSEN, Theodorus (ed). Iordanis Romana et Getica. Berolini: Apud Weidmannos: 1882. Monumenta Germaniae Historia. Autorum Antiquissimorum Tomi V Pars Prior.

${ }^{5}$ Para uma discussão detalhada, vide LÖFSTEDT (1959, pp. 1-38).

${ }^{6}$ Iordanes, De Origine Actibusque Getarum vel Getica, 50.266: “ego item quamvis agramatus Iordannis ante conversionem meam notarius fui” (Eu, Jordanes, igualmente, apesar de pouco estudado (agramatus) antes de minha conversão, fui notário).
} 
Martin e Rose denominam “avaliatividade” (appraisal) o aspecto da metafunção interpessoal que possibilita ao emissor informar ao receptor qual a sua opinião a respeito do que está dizendo. A rigor, a avaliatividade pode ser considerada a partir de três aspectos textuais: (1) "atitude" (attitude), (2) "amplificação" (amplification); e (3) "comprometimento"7 (engagement). O primeiro deles é o mais importante, visto que carrega uma maior carga de conteúdo semântico. É através da "atitude" que o emissor expressa "afeto" (affect), "julgamento" (judgement) e "apreço" (appreciation); sendo que cada um desses se relaciona, respectivamente, com sentimentos, caráter e valor.

A “amplificação", por seu turno, é usualmente obtida através do recurso a "intensificadores" - o que muito comumente identificamos como advérbios ou locuções adverbiais. Tal "léxico atitudinal" (attitudinal lexis) não opera sozinho, dependendo sobremaneira de "palavras de conteúdo" ou, mais tecnicamente, "itens lexicais" (lexical items). Além desse aspecto de "força" (force), a rigor, a amplificação pode ser conseguida também através do "foco" (focus), resultado do emprego de palavras ou expressões como "precisamente”, "por volta de”, "não exatamente”, etc.

O último dos três aspectos textuais da avaliatividade é o “comprometimento” (engagement), que diz respeito a quais vozes se expressam no texto. Por exemplo, a narrativa de Jordanes pode trazer avaliações em nome do próprio autor ou das "personagens" de sua trama - como “os romanos”, “o imperador”, “os visigodos”, etc.

Em nossa tese de doutoramento em História na Universidade Federal de Ouro Preto, inicianda em 2015 sob a orientação do Prof. Dr. Fábio Duarte Joly, pretendemos discutir como Jordanes apresenta os godos na Getica, tanto em contraste com outros povos "bárbaros" como com os romanos. Em outras palavras, discutiremos questões relacionadas à "avaliatividade" na narrativa jordaneana. Nossa própria prática tradutória foi adaptada para tanto. Como a análise da avaliatividade dá-se sobretudo no campo lexical, tivemos um cuidado especial com as palavras que de algum modo qualificavam as personagens, procurando nos ater metódica e rigorosamente ao texto latino quando as traduzíamos.

Nossa abordagem talvez fique mais clara através de um exemplo. No passo 225, Jordanes, ou melhor, o narrador refere-se a Átila como "versutus et callidus". Em sua tradução para o Inglês, Mierow verteu esses termos como "shrewd and crafty”; enquanto Sánchez Martín produziu, em Espanhol, "taimado y astuto”. Ora, Jordanes está apenas chamando Átila de "versado e calejado" - ambas metáforas, aliás, empregadas ainda hoje em nossa língua. Esse tipo de uso em sequência de palavras de acepções semelhantes numa mesma oração é bastante comum no Latim Tardio e devia servir tanto para intensificar quanto para esclarecer o significado da primeira delas. Em outras palavras, Jordanes está dizendo que Átila era um sujeito muito experiente. É certo que tamanha experiência tenha feito com que Átila se tornasse também astuto; sendo que "shrewd and crafty" e "taimado y astuto" tentam dar conta disso. Na passagem em questão, a propósito, o rei dos hunos tenta confundir os romanos ao deslocar suas tropas de modo imprevisível. Ainda assim, tanto "shrewd and crafty" como "taimado y astuto" não equivalem funcionalmente a "versutus et callidus", como é o caso de "versado e calejado", porquanto expandem o sentido do original.

${ }^{7}$ Para a tradução do termo “engagement”, seguimos Souza (2011, pp. 85-87). 
Vejamos outro exemplo. No passo 182, Jordanes escreveu o seguinte: "forma brevis, lato pectore, capite grandiore, minutis oculis, rarus barba, canis aspersus, semo nasu, teter colore, origenis suae signa restituens". Temos aí uma descrição do aspecto físico de Átila, traduzida da seguinte forma por Mierow, por Sánchez Martín e por nós, respectivamente:

He was short of stature, with a broad chest and a large head; his eyes were small, his beard thin and sprinkled with gray; and he had a flat nose and a swarthy complexion, showing evidences of his origin.

De estatura era bajo, ancho de pecho, de cabeza grande y ojos pequeños; la barba la tenía poco poblada, los cabellos canosos, la nariz aplastada y la tez oscura, rasgos todos ellos que denotaban su raza.

Era baixo, de peito largo, cabeça grande, olhos pequenos; a barba [era] rala e salpicada de branco; tinha o nariz achatado e a cor horrível - sinais que demonstravam sua origem.

Analisemos as diferenças. Independentemente de Jordanes ter mudado o gênero da palavra "barba" para o masculino, é bastante claro que esta pode ser dita "thin", "poco poblada" ou "rala”. O que vem em seguida, porém, é ambíguo. "Canis" é a forma que o adjetivo "canus" assume nos casos dativo e ablativo. Trata-se de um adjetivo usado normalmente para se descrever cabelos e barbas. "Aspersus" significa "espalhado", “disperso". "Canis aspersus" seria algo como "salpicado de branco". Mas o que "salpicado de branco"? Não é possível ter certeza. Nós, assim como Mierow, consideramos que Jordanes continua a se referir à barba de Átila, enquanto Sánchez Martín crê que o autor passou a se referir aos cabelos. Obviamente, a questão de se Átila tinha barba ou cabelos grisalhos é absolutamente banal. Por outro lado, a discussão aqui centra-se em como se pode compreender - ou não - algo que foi escrito em Latim há quatorze séculos e meio.

O trecho inteiro é de difícil leitura. Jordanes, em seguida, comete o que seriam dois erros de ortografia no Latim clássico: escreve "semo" em vez de "simo" e "teter" em vez de "taeter". Ambos são perfeitamente explicáveis pelas transformações na pronúncia da língua ao longo dos séculos, mas, ainda assim, deles resulta o risco de o leitor/tradutor não reconhecer essas palavras e tampouco encontrá-las em algum dicionário. A palavra "nasus" não chega a causar maiores problemas, apesar de Jordanes flexioná-la como se pertencesse à quarta declinação e não à segunda. "Semo nasu", por estar no caso ablativo, significaria "com o nariz achatado" ou "de nariz achatado". Não nos parece problemático que Mierow e Sánchez Martín tenham escrito, respectivamente, "and he had a flat nose" e "la nariz aplastada". Tivemos, também, que nos resignar a escrever "tinha o nariz achatado", para que o trecho em questão ficasse coerente.

A grande diferença nas três traduções do trecho em questão, porém, está no termo "teter". Quando verificamos "teter" no Oxford Latin Dictionary, vimos que esse verbete remete o leitor a "taeter". Ali, na página 1900, encontram-se três acepções: (1) "Physically offensive, foul, horrible, b (of animals, monsters, etc.). c (of smell, taste, sound, etc.)"; (2) "of persons, etc.) Morally offensive, vile, abominable” e (3) “(of actions, experiences, etc.) Monstruous, vile, horrible”. Outros dicionários em língua inglesa e um em língua espanhola traziam acepções semelhantes. 
A essa altura do processo tradutório, a questão parecia-nos resolvida: Mierow e Sánchez Martín, como no caso de "versutus et callidus", haviam expandido o sentido do original. Afinal, Jordanes havia dito que a cor de Átila era "horrível” (ou ao menos “desagradável”) e os dois tradutores haviam convertido isso em "swarthy complexion" e "tez oscura". Em outras palavras, ambos haveriam neutralizado o juízo de valor de Jordanes. Foi então que, enquanto escrevíamos o presente comentário, decidimos checar um último dicionário, dessa vez o LatinoPortuguês de F. R. dos Santos Saraiva. Nele, o verbete "tētěr ou tǣtěr, tră, trŭm" (página 1195) se inicia com "adj. Lucr. Virg. Negro, escuro, sombrio. Tetrce notce. Lucr. Manchas denegridas - tenebrce. Cic. Trevas profundas” e depois segue com acepções semelhantes às do Oxford Latin Dictionary.

Esse é, ainda assim, um dos casos nos quais não se pode ter absoluta certeza quanto ao sentido do que foi escrito. É possível que Jordanes considerasse que Átila em particular, ou os hunos de modo geral, tivessem uma "cor horrível"; mas também é possível que ele simplesmente estivesse afirmando que eram morenos. Se, todavia, o sentido de "teter" como "escuro" não estivesse dicionarizado, seria possível dizer que, no trecho em questão, as traduções de Mierow e Sánchez Martín não equivaliam funcionalmente ao original, por conta de terem neutralizado o juízo de valor de Jordanes e interferido no aspecto avaliativo do texto. Por fim, depois de muito ponderar a questão, decidimo-nos por seguir Mierow e Sánchez Martín, de modo que nossa versão final traz "tinha o nariz achatado e a cor escura”.

\section{Sobre os comentários ao texto}

O leitor encontrará, nas páginas seguintes, o trecho da Getica que faz referência a Átila - tanto no original latino como em nossa tradução para o Português. Cada um dos breves capítulos do referido trecho é seguido de comentários nossos, que versam sobre questões de cunho propriamente histórico, assim como sobre questões relativas à avaliatividade (mormente relacionadas a Átila), a aspectos da composição (como elementos retóricos do texto) e a questões tradutórias.

O motivo para que todos os comentários apareçam misturados reside, em última análise, na discussão da avaliatividade na Getica, parte importante da nossa tese de doutoramento. Se discutíssemos a avaliatividade somente a partir do original latino, nossa análise seria de difícil compreensão por parte de um nãolatinista. Ocorre, porém, que uma investigação acerca tanto do fim do Império Romano do Ocidente como das chamadas "invasões bárbaras” é de interesse não apenas de latinistas. A solução que elegemos para tal problema foi a de produzir uma versão em Português do texto escrito por Jordanes que preservasse ao máximo a avaliatividade expressa no original. Ora, produzir uma tradução rigorosa de um relato histórico envolve questões de interpretação que vão além do aspecto meramente linguístico ou textual: quando o texto apresenta uma negociação entre líderes, é preciso que se compreenda tanto o seu contexto político quanto a perspectiva adotada pelo autor diante desse; ademais, quando o texto refere-se ao deslocamento de tropas, que se compreenda, com a maior precisão possível, que locais estão sendo mencionados e que caminhos estão sendo percorridos; quando o que se apresenta é um relato de uma batalha, que se compreenda como o cenário em questão foi imaginado pelo autor e em que medida ele poderia ou não corresponder 
a um cenário real; e assim por diante. A discussão de elementos como esses não é, strictu sensu, tradutória. Ela faz, por outro lado, parte do processo interpretativo indispensável não apenas ao trabalho de tradução de um relato histórico como também pode resultar na produção de elementos paratextuais que facilitem a compreensão do texto já traduzido, o que cremos ter sido o caso.

As notas de rodapé, por sua vez, trazem questões que consideramos de importância secundária; além de esclarecimentos sobre os “erros” ortográficos encontrados no texto de Jordanes.

Gustavo H. S. S. Sartin 


\author{
De Origine Actibusque \\ Gerarum vel Getica
}

\author{
Sobre a Origem e Feitos \\ dos Godos ou Getica
}

\section{XXXIV}

(176) Quid plurimum? defuncto Vallia, ut superius quod diximus repetamus, qui parum fuerat felix Gallis, prosperrimus feliciorque Theodoridus successit in regno, homo summa moderatione compositus, animi corporisque utilitate habendus. contra quem Theodosio et Festo consulibus pace rupta Romani Hunnis auxiliaribus secum iunctis in Galliis arma moverunt. turbaverat namque eos Gothorum foederatorum manus, qui cum Gaina comite Constantinopolim efferasset. Aetius ergo patricius tunc praerat ${ }^{8}$ militibus, fortissimorum Moesium stirpe progenitus in Dorostorena civitate a patre Gaudentio, labores bellicos tolerans, rei publicae Romanae singulariter natus, qui superbam Suavorum Francorumque barbariem immensis caedibus ${ }^{9}$ servire Romano imperio coegisset.

(177) Hunnis quoque auxiliariis Litorio ductante contra Gothos Romanus exercitus movit procinctum, diuque ex utraque parte acies ordinatae cum utrique fortes et neuter infirmior esset, datis dextris in pristina concordia redierunt, foedusque firmatum ab alterutrum fida pace peracta recessit uterque.

\section{Capítulo 34}

(176) O que mais? Repitamos o que dissemos acima: morto Valia, que pouco fora afortunado nas Galliae, sucedeu-lhe no reino Teodorico, extremamente próspero e mais afortunado - homem de extrema moderação e possuidor de grande capacidade física e espiritual. Durante o consulado de Teodósio e Festus, os romanos romperam a paz e moveram as armas até as Galliae contra ele, tendo os hunos como seus auxiliares; em razão das perturbações causadas pelas ações de federados dos godos que, com o conde Gainas, fizeram com que Constantinopolis se agitasse. O patrício Aécio, então o primeiro entre os soldados, era um mésio de uma linhagem valentíssima, nascido na cidade de Dorostorom ${ }^{12}$, tendo [um certo] Gaudêncio por pai. [Era um homem] capaz de suportar as exigências da guerra, nascido apenas para [servir] o Estado Romano; que através de grandes vitórias coagiu os soberbos bárbaros suevos e francos a servirem o Império Romano.

(177) O exército romano, também, sob o comando de Litório e tendo os hunos como auxiliares, moveu seus armamentos para enfrentar os godos. As linhas de batalha de cada lado ficaram dispostas por muito tempo e, como nenhuma era mais fraca, [os dois comandantes] cumprimentaram-se, retornando à antiga concórdia. Um tratado foi firmado por ambos e, diante da paz confiável, ambos [exércitos] retiraram-se.

\footnotetext{
${ }^{8}$ O original latino traz "praerat” em vez de "praeerat”.

${ }^{9}$ Jordanes diz, nesse trecho, que Aécio coagiu suevos e francos a servirem o Império Romano através de grandes "derrotas”. Estas, obviamente, seriam derrotas desses povos. Em Português, diríamo-lo de um modo diferente: Aécio coagiu suevos e francos através de grandes vitórias. Vitórias, nesse caso, de Aécio; mas que correspondem a derrotas desses dois povos.

${ }^{12}$ Atual Silistra, na Bulgária.
} 
(178) qua pace Attila, Hunorum omnium dominus et paene totius Scythiae gentium solus in mundo regnator, qui erat famosa inter omnes gentes claritate mirabilis. ad quem in legatione se missum a Theodosio iuniore Priscus istoricus ${ }^{10}$ tali voce inter alia refert: ingentia si quidem flumina, id est Tisia Tibisiaque et Dricca transientes venimus in loco illo, ubi dudum Vidigoia Gothorum fortissimus Sarmatum dolo occubuit; indeque non longe ad vicum, in quo rex Attila morabatur, accessimus, vicum inquam ad instar civitatis amplissimae, in quo lignea moenia ex tabulis nitentibus fabricata repperimus, quarum compago ita solidum mentiebatur, ut vix ab intentu possit iunctura tabularum conpraehendi.

(179) videres triclinia ambitu prolixiore distenta porticusque in omni decore dispositas. area vero curtis $^{11}$ ingenti ambitu cingebatur, ut amplitudo ipsa regiam aulam ostenderet. hae sedes erant Attilae regis barbariae tota tenenti; haec captis civitatibus habitacula praeponebat.
(178) Durante esta paz Átila era o senhor de todos os hunos e o único governante terredo de quase de todas as tribos da Scythia; era admirável por seu famoso brilho em meio a todos as tribos. O historiador Prisco, a ele enviado em embaixada por Teodósio II, entre outras coisas relata o seguinte: "Depois de atravessarmos rios realmente imensos - o Tisia, o Tibisia e o Dricca - chegamos àquele local, onde outrora Vidigoia, o mais valente dos godos, pereceu por conta da trapaça dos sármatas; e não longe dali acessamos a aldeia na qual Átila residia digo 'aldeia', mas à imagem de uma grandíssima cidade -, na qual encontramos muros de madeira feitos de tábuas polidas, cuja amarração fazia com que parecessem um todo sólido, de modo que era difícil, mesmo observando com atenção, perceber onde o ponto de junção das tábuas.

(179) Poderias ver grandes, bem dispostos e luxuosos salões de jantar e pórticos organizados com grande elegância. A área do pátio era, na verdade, rodeada por um perímetro enorme, como se a própria amplidão servisse para mostrar que se tratava da corte de um rei." Esta era a residência do rei Átila, possuidor de todo o mundo bárbaro, que preferia esta moradia às cidades que capturara.

\footnotetext{
10 “Istoricus” em vez de "historicus".

11 “Curtis” em vez de "cortis", genitivo de "cors".
} 


\section{Comentários ao capítulo 34 (176 - 179)}

O trecho que traduzimos tem início com a rememoração da ascensão de Teodorico ao trono dos visigodos, ocorrida em 418. Jordanes lhe tece grandes elogios: "extremamente próspero e mais afortunado - homem de suma moderação e possuidor de grande capacidade física e espiritual”. Note-se aí as amplificações, grifadas. A narrativa salta em seguida para o ano do "consulado de Teodósio e Festus" - ou seja, 439 - no qual estaria a ocorrer um novo conflito entre os visigodos e os romanos - que contariam com o auxílio dos hunos. O fluxo narrativo é, então, interrompido e, sem motivo aparente, somos apresentados à figura de Aécio, homem "capaz de suportar as exigências da guerra, nascido apenas para [servir] o Estado Romano". Sob sua liderança, tanto suevos como francos teriam sido coagidos a acompanhar os romanos em batalhas.

O conflito é retomado no passo seguinte (177) e então ficamos sabendo da força dos visigodos. Os romanos, mesmo auxiliados pelos hunos, não teriam ousado enfrentá-los; de modo que um acordo de paz acaba sendo firmado.

Em seguida, somos apresentados a Átila (178 e 179). Jordanes vale-se do testemunho do historiador Prisco de Panium, certa feita foi enviado à corte de Átila

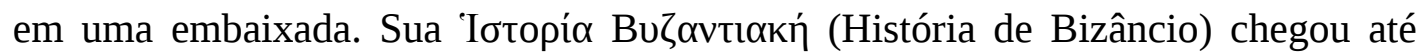
nossos dias bastante fragmentada, mas teve grande influência no mundo bizantino. Jordanes vale-se dela com parcimônia, selecionando apenas os trechos convenientes ao próprio projeto historiográfico. Os excertos por ele citados nesse ponto aludem a um dos locais de moradia de Átila: construído com sofisticação; luxuoso e elegante; além de amplo. Talvez Jordanes esteja a nos alertar de que se trata de um homem sofisticado, não de um bruto. 


\section{$X X X V$}

(180) Is namque Attila patre genitus Mundzuco, cuius fuere germani Octar et Roas, qui ante Attilam regnum tenuisse narrantur, quamvis non omnino cunctorum quorum ipse. post quorum obitum cum Bleda germano Hunnorum successit in regno, et, ut ante expeditionis, quam parabat, par foret, augmentum virium parricidio quaerit, tendens ad discriminem omnium nece suorum.

(181) sed librante iustitia detestabili remedio crescens deformes exitus suae crudelitatis invenit. Bleda enim fratre fraudibus interempto, qui magnae parti regnabat Hunnorum, universum sibi populum adunavit, aliarumque gentium, quas tunc in dicione tenebat, numerositate collecta, primas mundi gentes Romanos Vesegothasque subdere praeoptabat.

(182) Cuius exercitus quingentorum milium esse numero ferebatur. vir in concussione gentium natus in mundo, terrarum omnium metus, qui, nescio qua sorte, terrebat cuncta formidabili de se opinione vulgata. erat namque superbus incessu, huc atque illuc circunferens oculos, ut elati potentia ipso quoque motu corporis appareret; bellorum quidem amator, se ipse manu temerans, consilio validissimus, supplicantium exorabilis, propitius autem in fide semel susceptis; forma brevis, lato pectore, capite grandiore, minutis oculis, rarus barba, canis aspersus, semo nasu, teter colore, origenis suae signa restituens.

\section{Capítulo 35}

(180) Este Átila era, pois, o filho de Mundiuco, cujos irmãos foram Octar e Roas, e que conta-se que reinaram antes de Átila, ainda que não sobre tantos quanto ele próprio. Após as suas mortes, [Átila] ascendeu ao trono com o irmão Bleda; e, para que estivesse à altura da expedição que preparava, buscou 0 aumento de poder através da morte de um parente - partindo da distinção entre os seus para a distinção entre todos.

(181) Mas o sucesso crescente da sua crueldade deformada viria a ter remédio através da balança da justiça. [Átila], assim - estando o [seu] irmão Bleda, que havia reinado sobre grande parte dos hunos, destruído por conta de trapaças - reuniu em torno de si todo o povo, além de outras tribos, que agora tinha sob o seu comando. Com tal multidão reunida, preferiu submeter as primeiras dentre as tribos do mundo, os romanos e os visigodos.

(182) Dizia-se que seu exército tinha quinhentos mil [homens]. Era um homem nascido para chacoalhar as tribos do mundo, o terror de todas as terras; [um homem] que, não sei por que sorte, aterrorizava a todos com a sua pavorosa reputação. Tinha, pois, um andar soberbo e seus olhos se moviam de um lado a outro, como que também para que potência que trazia se manifestasse através de seu movimento corporal. Ainda que fosse um amante da guerra, restringia a própria mão. Era um excelente conselheiro, tolerante com o suplicante e favorável, ademais, aos que uma vez aceitara em confiança. Era baixo, de peito largo, cabeça grande, olhos pequenos; a barba [era] rala e salpicada de branco; tinha o nariz achatado e a cor escura - sinais que demonstravam sua origem. 
(183) qui quamvis huius esset naturae, ut semper magna confideret, addebat ei tamem confidentia gladius Martis inventus, sacer apud Scytharum reges semper habitus, quem Priscus istoricus tali refert occasione detectum. cum pastor, inquiens, quidam gregis unam boculam ${ }^{13}$ conspiceret claudicantem nec causam tanti vulneris inveniret, sollicitus vestigia cruoris insequitur tandemque venit ad gladium, quem depascens herbas incauta calcaverat, effossumque protinus ad Attilam defert. quo ille munere gratulatus, ut erat magnanimis, arbitratur se mundi totius principem constitutum et per Martis gladium potestatem sibi concessam esse bellorum.
(183) Ainda que, por natureza, sempre confiasse que realizaria grandes feitos, a sua confiança ainda foi aumentada com a descoberta da espada de Marte, sempre tida como sagrada pelos reis da Scythia, cujo achado assim foi relatado pelo historiador Prisco: “Quando um vaqueiro observou uma das novilhas de seu rebanho mancando, mas não encontrava o que poderia ter causado tamanho ferimento, seguiu preocupado com as marcas de sangue e acabou por descobrir a espada que a incauta novilha pisoteara enquanto pastava. Excavou-a e entregou-a imediatamente a Átila. Este ficou grato pelo favorecimento e, como era ambicioso, passou a considerar que fora designado príncipe do mundo inteiro e que através da espada de Marte lhe fora concedido o poder nas guerras.” 


\section{Comentários ao capítulo 35 (180 - 183)}

Jordanes inicia o capítulo relatando a origem de Átila e sua ascensão à posição de comandante único dos hunos, que teria se dado por volta do ano 445 $(180)^{14}$. Fica evidente que, para o autor da Getica, Átila era um homem cujas ambições não eram freadas por maiores considerações éticas: "buscou o aumento de poder através da morte de um parente". No passo seguinte, porém, Jordanes recorre a uma prolepsis (ou "flash-forward"), informando-nos que a "crueldade deformada” de Átila viria a ser remediada através da balança da justiça. Note-se novamente o recurso à amplificação, grifada. Sua ambição o teria levado a almejar a destruição de romanos e visigodos, "as primeiras dentre as tribos do mundo" outra amplificação.

O olhar retrospectivo é uma característica inevitável do trabalho do historiador e acaba por situá-lo no próprio tempo. Alguém, por exemplo, que em 1985 quisesse contar a história das greves do Grande ABC ocorridas em 1978, necessariamente acabaria por fazer um trabalho muito diferente de quem se dispusesse a contar essa mesma história vinte anos mais tarde. Em 1985, o principal líder do movimento grevista, Luiz Inácio “Lula” da Silva, era apenas o presidente do recém-criado Partido dos Trabalhadores. Em 2005, porém, o mesmo homem estaria a ocupar a presidência do Brasil. É quase inevitável, então, que o historiador posterior examinasse as greves de 1978 com um olhar que, conscientemente ou não, buscasse sinais do que viria pela frente. O mesmo se dá, mutatis mutandis, com Jordanes. Ele sabe, quase um século no futuro, que Átila não apenas enfrentará romanos, como também que acabará derrotado. Ao examinar a vida do rei dos hunos, ele parece buscar desde o início explicações para o que está por vir.

Retomemos a narrativa de Jordanes. Átila, mesmo que estivesse destinado a um dia encontrar a derrota, "era um homem nascido para chacoalhar as tribos do mundo, o terror de todas as terras”. Note-se outra amplificação: Átila não teria sido simplesmente um terror, mas um terror que assolou todas as terras do mundo. O texto continua com uma descrição do rei dos hunos, desde os trejeitos às características físicas, passando também por alguns elementos morais ou psicológicos (182). É razoável nos questionarmos, nesse ponto, qual a fonte de algumas dessas informações, dado que os antigos eram pouco afeitos a registrar características físicas. Átila é retratado como alguém altivo porém agitado: “tinha, pois, um andar soberbo e seus olhos se moviam de um lado a outro, como que também para que potência que trazia se manifestasse através de seu movimento corporal”; além de comedido, sábio e generoso para com os seus: "restringia a própria mão”, “ excelente conselheiro”, “tolerante com o suplicante e favorável [...] aos que uma vez aceitara em confiança”. Fisicamente, "era baixo, de peito largo, cabeça grande, olhos pequenos; a barba [era] rala e salpicada de branco; tinha o nariz achatado e a cor escura - sinais que demonstravam sua origem”. É possível que, com a última declaração, Jordanes esteja a nos sinalizar que tal descrição física não passa de um estereótipo.

Em seguida, no passo 183, Jordanes dá voz novamente a Prisco, que narra uma historieta na qual um pastor encontra a espada do deus Marte e a entrega a Átila. Tal episódio, segundo Jordanes, teria aumentado a autoconfiança do rei dos hunos. Coloca-se aí, mais uma vez, a questão da visão retrospectiva: Jordanes tenta

14 Segundo C. D. Gordon (1961, p. 61), Átila teria assassinado o irmão em 445. 
explicar como Átila encontrou coragem para enfrentar "as primeiras entre as tribos do mundo".

Podemos considerar os capítulos 34 e 35 como preâmbulos do que virá em seguida. Jordanes apresentou-nos, neles, os três principais comandantes da batalha dos campos Cataláunicos: Teodorico, Aécio e Átila. 


\section{$X X X V I$}

(184) Huius ergo mentem ad vastationem orbis paratam comperiens Gyzericus, rex Vandalorum, quem paulo antem memoravimus, multis muneribus ad Vesegotharum bella precipatat, metuens, ne Theoderidus Vesegotharum rex filiae suae ulcisceretur iniuriam, quae Hunerico Gyzerici filio iuncta prius quidem tanto coniugio laetaretur, sed postea, ut erat ille et in sua pignora truculentus, ob suspictionem tantummodo veneni ab ea parati, naribus abscisam trucatamque auribus, spolians decori naturali, patri suo ad Gallias remiserat, ut turpe funus miseranda semper offerret et crudelitas, qua etiam moverentur externi, vindictam patris efficacius impetraret.

(185) Attila igitur dudum bella concepta Gyzerici redemptione parturiens, legatos in Italia ad Valentinianum principem misit, serens Gothorum Romanorumque discordia, ut, quos proelio non poterat concutere, odiis internis elideret, asserens, se rei publicae eius amicitias in nullo violare, se contra Theoderidum Vesegotharum regem sibi esse certamen. unde cum excipi liberter optaret, citera epistula usitatis salutationum blandimentis oppleverat, studens fidem adhibere mendacio.

(186) pari etiam modo ad regem Vesegotharum Theoderidum dirigit scripta, hortans, ut a Romanorum societate discederet: recoleretque proelia, quae paulo ante contra eum fuerant concitata. sub nimia feritate homo subtilis ante quam bella gereret arte pugnabat. tunc Valentinianus imperator ad Vesego-

\section{Capítulo 36}

(184) Quando então Giserico, rei dos vândalos, a quem nos referimos há pouco, percebeu que a mente [de Átila] estava decidida pela devastação do mundo, muitos presentes [enviou-lhe] para que iniciasse a guerra com os visigodos, temendo que o rei visigodo Teodorico vingasse a injúria à filha. Ela anteriormente alegrara-se ao ser unida em matrimônio com Hunerico, filho de Giserico. Depois, porém, por ele ser truculento [mesmo] com os seus protegidos, decepou-lhe o nariz e as orelhas apenas por suspeitar de que ela lhe houvesse preparado um veneno, privandoa de sua elegância natural. Enviou-a de volta ao pai, nas Galliae, onde ela sempre exibiria, miseravelmente, seu aspecto morredouro. [Tamanha] crueldade, que comovia inclusive os estrangeiros, requeria ainda mais eficazmente a vingança do pai.

(185) Átila, assim, dando início à guerra concebida por Giserico, enviou à Itália embaixadores ao imperador Valentiniano, como se, não podendo amedrontar [o inimigo] com a perspectiva de um combate, [ao menos] pudesse dividi-lo através dos ódios internos. Declarava que não estava a violar de modo algum a amizade com o Império, mas que estava em disputa com o rei dos visigodos Teodorico. Como se desejasse ser bem recebido, cobriu o resto da carta com as saudações elogiosas usuais, procurando obter confiança através da mentira.

(186) Do mesmo modo, enviou uma mensagem ao rei visigodo Teodorico, exortando-o a sair da aliança com os romanos e relembrando os combates pouco antes realizados [pelos romanos] contra ele. Sob a excessiva ferocidade, existia um homem astuto, que, antes de fazer guerra, lutava através de artifícios. Então o imperador Valentiniano enviou 
thas eorumque regem Theoderidum in his verbis legationem direxit:

(187) 'prudentiae vestrae est, fortissimi gentium, adversus orbis conspirare tyrannum, qui optat mundi generale habere servitium, qui causas proelii non requirit, sed, quidquid commiserit, hoc putat esse legitimum. ambitum suum brachio metitur, superbiam licentia satiat; qui ius fasque contemnens, hostem se exhibet et naturae. cunctorum etenim meretur hic odium, qui in commune omnium se adprobat inimicum.

(188) recordamini, quaeso, quod certe non potest oblivisci. ad Hunnis non per bella, ubi comunis casus est, fusum, sed, quod graviter anget, insidiis appetitum. ut de nobis taceamus, potestis hanc inulti ferre superbiam. armorum potentes favete propriis doloribus et communes iungite manus. auxiliamini etiam rei publicae, cuius membrum tenetis. quam sit autem nobis expetenda vel amplexanda societas, hostis interrogate consilia'.

(189) his et similia legati Valentiniani regem permoverunt Theodoridum. quibus ille respondit: 'habetis'. inquid, 'Romani, desiderium vestrum; fecistis Attilam et nobis hostem. sequimur illum quocumque vocaverit, et quamvis infletur de diversis gentium victoriis, norunt tamen Gothi confligere cum superbis. nullum bellum dixerim grave, nisi quod causa debilitat, quando nil triste pavet, cui maiestas adriserit'. adclamant responso comites duci, laetus sequitur vulgus. uma embaixada aos visigodos e ao seu rei Teodorico, com esta mensagem:

(187) "Para vós, que sois a mais valente das tribos, o mais prudente é conspirar contra o tirano do mundo, que deseja escravizar toda a humanidade, não necessita de motivos para envolver-se em combates e considera tudo o que faz legítimo. Ele mede a ambição pelo próprio braço e sacia a soberba com permissividade, desprezando a justiça humana e divina, mostrando-se um inimigo [da própria] natureza. Merece, portanto, o ódio geral, pois se revela o adversário comum a todos.

(188) Peço que recordeis aquilo que não podeis esquecer: os hunos não operam através da guerra, na qual as chances são iguais, mas atormentam [seus inimigos] com emboscadas, o que é mais grave. Sem que digamos algo a nosso respeito, podeis vós suportar tal soberba sem puni-la? Favorecei-nos em nosso sofrimento, pois possuis exércitos poderosos, e uni vossas mãos às nossas. Auxiliai também o Império, já que tens parte nele. Se quereis saber o quanto aguardamos de braços abertos uma aliança [convosco], inqueri sobre os planos do inimigo."

(189) Com estes e semelhantes [argumentos], os embaixadores de Valentiniano convenceram Teodorico, que lhes respondeu: “Obtivestes”, disse, “ó romanos, o que desejastes; tornastes-nos inimigos de Átila. Perseguiremo-lo onde quer que ele faça barulho, ainda que esteja inflado pelas vitórias sobre diversos povos, os godos todavia sabem como lutar contra os soberbos. Eu diria que nenhuma guerra é grave, a não ser aquela feita por motivos débeis; e nada triste deve temer aquele que favorece a [própria] soberania." Os companheiros [do rei] aplaudem a resposta do [seu] líder e o povo os segue alegremente. 
(190) fit omnibus ambitus pugnae, hostes iam Hunni desiderantur. producitur itaque a rege Theodorido Vesegottharum innumerabilis multitudo; qui quattor filios domi dimissos, id est Friderichum et Eurichum, Retemerim et Himnerith secum tantum Thorismud et Theodericum ${ }^{15}$ maiores natu participes laboris adsumit. felix procinctum, auxilium tutum, suave collegium habere solacia illorum. quibus delectat ipsa etiam simul subire discrimina.

(191) a parte vero Romanorum tanta patricii Aetii providentia fuit, cui tunc innitebatur res publica Hesperiae plagae, ut undique bellatoribus congregatis adversus ferocem et infinitam multitudinem non impar occurreret. hi enim adfuerunt auxiliares: Franci, Sarmatae, Armoriciani, Liticiani, Burgundiones, Saxones, Ripari, Olibriones, quondam milites Romani, tunc vero iam in numero auxiliarium exquisiti, aliaeque nonnulli Celticae vel Germanie nationes.

(192) convenitur itaque in campos Catalaunicos, qui et Mauriaci nominantur, centum leuvas, ut Galli vocant, in longum tenentes et septuaginta in latum. leuva autem Gallica una mille et quingentorum passum quantitate metitur. fit ergo area innumerabilium populorum pars illa terrarum. conseruntur acies utraeque fortissimae; nihil supreptionibus agitur, se aperto Marte certatur.
(190) Todos estavam prontos para a luta, ansiando pelos inimigos hunos. E assim uma multidão incontável é produzida pelo rei dos visigodos, que deixa em casa quatro filhos: Friderico, Eurico, Retemero e Himnerico; levando consigo apenas os mais velhos, Torismundo e Teodorico [II]. Feliz preparação, defesa segura e doce camaradagem é ter o conforto daqueles que se deleitam compartilhando as mesmas preocupações.

(191) No lado dos romanos, na verdade, foi tão grande a precaução do patrício Aécio, de quem então dependia a parte ocidental do Império, que ele congregou de todos os cantos guerreiros capazes de fazer par à feroz e incontável multidão do inimigo. Esses foram, então, os que lhe acompanharam como tropas auxiliares: francos, sármatas, armoricanos, liticianos, burgúndios, saxões, ripários e os olibriões - que certa feita foram soldados romanos buscados, na verdade, para compor apenas as tropas auxiliares -, além de algumas outras nações celtas e germânicas.

(192) E assim se encontraram nos campos Cataláunicos, ${ }^{16}$ também chamados "Mauriacos", e que têm cem léguas de comprimento e setenta de largura, como dizem os gauleses. A légua gaulesa é uma medida de mil e quinhentos passos. Aquele pedaço de terra, então, recebeu incontáveis povos. Enfrentaram-se duas linhas de batalha valentíssimas. Nada foi feito às escondidas, mas disputado em batalha aberta.

\footnotetext{
${ }^{15} \mathrm{O}$ texto latino distingue entre os nomes "Theodoridus", do pai, e "Theodericus”, do filho. A rigor, o primeiro deveria ser aportuguesado como "Teodorido” e o segundo como "Teoderico”. A tradição, porém, trata-os como “Teodorico I" e “Teodorico II”.

${ }^{16}$ Nas adjacências da cidade de Catalaunum (atual Châlons-en-Champagne, na França).
} 
(193) quae potest digna causa tantorum motibus invenire? aut quod odium in se cunctos animavit armari? probatum est homanum genus regibus vivere, quando unius mentis insano impetu strages sit facta populorum et arbitrio superbi regis monumento defecit quod tot saeculis natura progenuit.
(193) Que causa digna se pode descobrir no movimento de tantos? Ou que ódio os animou a se armarem uns contra os outros? Está provado que o gênero humano vive por seus reis, porquanto a mente insana de um único foi causa da carnificina de [muitos] povos e pelo arbítrio de um rei soberbo se destruiu aquilo que a natureza levou séculos para gerar. 


\section{Comentários ao capítulo 36 (184 - 193)}

O capítulo se inicia com uma intriga palaciana. Jordanes nos conta que a aliança entre visigodos e vândalos teria sido quebrada pela truculência e suspeição do filho do rei destes, que desfigurara sua esposa, filha do rei daqueles. Temendo a vingança, o rei dos vândalos teria recorrido a Átila, cuja mente "estava decidida pela devastação do mundo”. Tal afirmação, num certo sentido, ecoa o que se lê no final do passo 180, quando Jordanes deixa claro que a ambição do rei dos hunos teria feito com que partisse da busca da "distinção entre os seus para a distinção entre todos”. É difícil datar com precisão eventos como o que teria posto visigodos e vândalos em lados opostos sem poder contar com informações adicionais, mas é provável que se trate de algo ocorrido entre fins de 449 e início de 450.

No passo 185, vemos que Átila teria cedido aos apelos do rei dos vândalos e enviado uma embaixada ao imperador do ocidente, Valentiniano. Além de ambicioso, o rei dos hunos é retratado por Jordanes como ardiloso: "não podendo amedrontar [o inimigo] com a perspectiva de um combate, [ao menos] pudesse dividi-lo através dos ódios internos". A embaixada teria tido por objetivo convencer os romanos de que não fossem em auxílio dos visigodos caso Átila os atacasse. O estratagema mencionado por Jordanes, narrador onisciente, fica mais claro no passo seguinte, (186). Nele lê-se a respeito de uma mensagem do rei dos hunos a Teodorico, rei dos visigodos, exortando-o para que pusesse fim na aliança com os romanos. O rei dos hunos teria buscado, portanto, a dissolução da aliança entre visigodos e romanos por ambos os lados. Jordanes reforça, então, o que havia dito anteriormente: "Sob a excessiva ferocidade, existia um homem astuto, que, antes de fazer guerra, lutava através de artifícios” - note-se a amplificação.

Na sequência, Jordanes dá voz a Valentiniano através de uma epístola a Teodorico. O imperador do ocidente, nela, reafirma o status especial dos visigodos - coisa que o próprio Jordanes já havia feito nos passos 177 e 181 - referindo-se a estes como "a mais valente das tribos". Átila é descrito como um "tirano do mundo, que deseja escravizar toda a humanidade, não necessita de motivos para envolver-se em combates e considera tudo o que faz legítimo" - note-se as amplificações. Além disso, a injustiça de suas ações faria dele um "inimigo [da própria] natureza” e “ adversário comum a todos”. Em outras palavras, a fala de Valentiniano serve não somente para reforçar o que o autor/narrador já havia dito acerca dos visigodos, mas também para esclarecer-nos os motivos pelos quais Átila deve ser detido: sua ambição não conhece limites; ele não respeita regra alguma; é soberbo. Não apenas, aliás, os atos do rei dos hunos são desprovidos de justiça, mas o próprio modo de lutar da tribo é questionado: “os hunos não operam através da guerra, na qual as chances são iguais, mas atormentam [seus inimigos] com emboscadas, o que é mais grave" - note-se outra amplificação (188).

Cabe ressaltar, a essa altura, que os historiadores antigos geralmente não tinham acesso a cartas como essa e tampouco a transcrições dos discursos dos líderes políticos e militares. A carta de Valentiniano a Teodorico é um mero dispositivo literário, criado a partir do que R. G. Collingwood costumava chamar de “imaginação histórica”. Em outras palavras, Jordanes deve ter se perguntado algo do tipo: "Naquelas circunstâncias, o que Valentiniano teria escrito a Teodorico para que este aceitasse unir-se a ele?” Tal pergunta pode ser respondida de diversas maneiras, conforme não somente ao que se acredita que sejam "as circunstâncias", mas também quem sejam Valentiniano e Teodorico, os romanos e os visigodos. 
Antes de prosseguirmos, consideremos um último período da epístola em questão: “Auxiliai também o Império, já que tens parte nele”. Ao atribuir ao imperador do ocidente a declaração de que os visigodos têm parte no Império, Jordanes parece estar defendendo a legitimidade do controle dos visigodos sobre territórios no sudoeste das Galliae. Os visigodos vinham ampliando seus domínios na região desde serem oficialmente instalados na região em 418, fato que desagradava ao governo imperial. A rigor, o simples fato de Valentiniano ter convidado Teodorico a unir-se a ele contra Átila já serviria como prova de que o Império reconhecia a legitimidade do reino dos visigodos. Ainda assim, é parte da agenda de Jordanes legitimar os godos perante os romanos e essa é uma boa oportunidade para fazê-lo.

A história continua com a resposta de Teodorico. O rei dos visigodos teria justificado a aceitação do pedido de Valentiniano por conta da soberba de Átila, prontificando-se a persegui-lo "onde quer que ele faça barulho". Isso é até mais do que o imperador do ocidente teria pedido. Nesse ponto, Jordanes procura nos fazer crer que o heroísmo não seria uma qualidade restrita, entre os visigodos, ao rei. Após Teodorico proferir a sua resposta, "os companheiros [do rei] aplaudem a resposta do [seu] líder e o povo os segue alegremente” (189). Entre os visigodos, "todos estavam prontos para a luta, ansiando pelos inimigos hunos. E assim uma multidão incontável é produzida pelo rei dos visigodos” (190). Note-se as amplificações.

O texto segue com a preparação de visigodos e romanos para o combate contra as forças de Átila. Jordanes, após mencionar que os filhos mais velhos do rei Teodorico, Torismundo e Teodorico [II], tomarão parte no combate, faz questão de ressaltar a união dos visigodos: "Feliz preparação, defesa segura e doce camaradagem é ter o conforto daqueles que se deleitam compartilhando as mesmas preocupações.” (190). Do lado romano, a preparação teria ficado por conta do precavido Aécio, "de quem então dependia a parte ocidental do Império" (191). Nessa passagem, o autor recorre não ao aspecto de força da amplificação (que consistiria em algo como "somente de Aécio dependia o Império"), mas ao foco. Ele, em seguida, provê uma lista dos auxiliares dos romanos "francos, sármatas, armoricanos, liticianos, burgúndios, saxões, ripários e os olibriões [...], além de algumas outras nações celtas e germânicas”. É como se Jordanes dissesse que, embora visigodos e romanos encabecem a aliança contra as forças de Átila, os visigodos são fortes por si sós, enquanto os romanos o são com o auxílio de muitos povos.

O passo 193, o último do capítulo, é especialmente interessante porque nele Jordanes interrompe o fluxo narrativo em prol de uma digressão na qual declara que a "mente insana" de um "rei soberbo" foi a causa da "carnificina de [muitos] povos" e da destruição "[d]aquilo que a natureza levou séculos para gerar". Temos aí outro exemplo de prolepsis (o anterior foi no passo 181), porquanto, no que diz respeito ao tempo narrativo, a guerra de hunos contra romanos e visigodos ainda não ocorreu. Ainda assim, Jordanes culpa Átila pelos resultados do conflito. Talvez o faça com a intenção de reforçar para os leitores quem são os heróis e quem são os vilões nessa guerra; ou quiçá simplesmente esteja preparando-os para o que está por vir. 


\section{$X X X V I I$}

(194) Sed antequam pugnae ipsius ordinem referamus, necessarium videtur edicere, quae in ipsis bellorum motibus acciderunt, quia sicut famosum proelium, ita multiplex atque perplexum. Sangibanus namque rex Alanorum metu futurorum perterritus Attilae se tradere pollicetur et Aurelianam civitatem Galliae, ubi tunc consistebat, in eius iura transducere.

(195) quod ubi Theodoridus et Aetius agnoverunt, magnis aggeribus eandem urbem ante adventum Attilae struunt, suspectumque custodiunt Sangibanum et inter suos auxiliares medium statuunt cum propria gente. igitur Attila rex Hunnorum tali perculsus eventu diffidens suis copiis metuit inire conflictum. inter que fugam revolvens ipso funere tristionem, statuit per aruspices futura inquirere.

(196) qui more solito nunc pecorum fibras, nunc quasdam venas in abrasis ossibus intuentes Hunnis infausta denuntiant; hoc tamen quantulum praedixere solacii, quod summus hostium ductor de parte adversa occumberet relictamque victoriam sua morte triumphum foedaret. cumque Attila necem Aetii, quod eius motibus obviabat, vel cum sua perditione duceret expetendam, tali praesagio sollicitus, ut erat consiliorum in rebus bellicis exquisitor, circa nonam diei horam proelium sub trepidatione committit, ut, si secus cederet, nox imminens subveniret.

\section{Capítulo 37}

(194) Mas antes de nos referirmos à própria ordem da luta, é necessário detalhar o que foi visto acontecer durante a preparação para a guerra, pois se o combate tornou-se famoso, também foi complexo e confuso. Uma vez que Sangibano, rei dos alanos, tomado pelo medo do futuro, promete entregar-se a Átila e transferir-lhe o controle sobre a cidade de Aureliana, nas Galliae, onde então habitava.

(195) Ao descobrirem isso, Teodorico e Aécio construíram uma grande barreira de terra em torno dessa mesma cidade antes da chegada de Átila, vigiando o suspeito Sangibano e colocando sua tribo em meio às próprias tropas auxiliares. Assim Átila, rei dos hunos, aborreceu-se de tal maneira com isso que perdeu a confiança no sucesso de suas próprias tropas e temeu dar início ao conflito e, enquanto se debatia sobre a fuga ser mais algo mais triste do que a derrota, decidiu inquirir os adivinhos acerca do futuro.

(196) Estes, como era hábito e costume, examinaram as entranhas do gado e perceberam que certos arranhões sobre os ossos raspados anunciavam insucesso para os hunos ainda que predicessem um pequeno consolo: que o condutor supremo do inimigo cairia e que sua morte enviuvaria a vitória e enfeiaria o triunfo. Átila, contudo, desejou a morte de Aécio, que impedia suas ações, mesmo que isso o conduzisse à [própria] destruição. Preocupado com tal predição, e como era um estudioso das estratégias militares, deu início ao combate na nona hora do dia, por nervosismo, para que, caso tivesse que fugir, a noite iminente sobreviesse. 


\section{Comentários ao capítulo 37 (194 - 196)}

Jordanes inicia o capítulo retrocedendo no tempo narrativo, com o fito de explicar como os alanos acabaram enfrentando Átila ao lado de visigodos e romanos. À época, sob o comando de Sangibano, os alanos ocupavam a cidade de Aureliana (atual Orleans, na França). Teodorico e Aécio teriam se valido de um cerco ao local para coagi-los a tomar parte na aliança contra Átila antes que este pudesse incorporá-los às próprias forças. ${ }^{17}$ Embora isso não fique claro nesse ponto, Sangibano não é rei de todos os alanos, apenas de um entre dois grupos. O outro, àquela altura dos acontecimentos, havia se misturado aos vândalos que ocupavam partes dos antigos domínios romanos no norte da África.

O autor apresenta-nos, em seguida, três novas facetas da personalidade de Átila: a insegurança, a compulsão pela desforra e a covardia. O rei dos hunos teria ficado tão aborrecido com o acréscimo desses alanos às forças de Teodorico e Aécio a ponto de perder a confiança nas próprias tropas e passar a temer o conflito (195). A insegurança de Átila o teria levado a consultar adivinhos, cuja predição teria sido a derrota dos hunos e a morte do "condutor supremo do inimigo" - notese a amplificação. O rei dos hunos, ainda assim, teria decidido-se pelo combate, desejoso de vingar-se de Áecio por este ter-lhe roubado o reforço dos guerreiros alanos. Átila teria decidido iniciar o combate na nona hora do dia - ou seja, no meio da tarde - por conta da preocupação com a predição, pois a noite lhe favoreceria a fuga caso fosse derrotado.

\footnotetext{
${ }^{17}$ Esse mesmo evento é contado em mais detalhes e de forma distinta por Gregório de Turones (Tours) em sua Historia Francorum (2.7; MIGNE, 1849, col. 198-199), finalizada em meados da década de 590. Na narrativa de Gregório, os cidadãos se desesperaram quando a cidade estava cercada pelo exército de Átila, de modo que o bispo Anniano/Aignan exortou-os para que se prostassem e orassem, implorando a Deus por auxílio. Isso feito, o bispo disse-lhes: “Observai da muralha da cidade se a misericórdia de Deus já [nos] socorre” (Aspicite de muro civitatis, si Dei miseratio iam succurrat). Ainda assim, não havia sinal da chegada de ajuda. O bispo então disselhes: “Orai com fé e então o Senhor vos libertará hoje” (Orate fideliter; Dominus enim liberavit vos hodie). Depois de o atenderem, os cidadãos observaram uma nuvem de poeira no horizonte e o chão começou a tremer. Eram Aécio, Teodorico e seu filho Torismundo chegando à cidade com os seus exércitos e pondo as forças de Átila em fuga. É certo, todavia, que Gregório não houvesse inventado tal versão do acontecido, porquanto Sidônio Apolinário a menciona de passagem em uma carta enviada a Próspero, então bispo de Aureliana e sucessor do tal Anniano/Aignan, talvez em fins da década de 470 (Epistolae, 8.15; MIGNE, 1847, col. 613-614). Na carta, Sidônio desculpa-se por não ter terminado de escrever a história de tal cerco: "Comecei a escrever, mas, quando percebi o tamanho da tarefa, lamentei que houvesse iniciado” (Coeperam scribere sed operis arrepti fasce perspecto taeduit inchoasse).
} 


\section{XXXVIII}

Capítulo 38
(197) Convenere partes, ut diximus, in campos Catalaunicos. erat autem positio loci declivi tumore in editum collis excrecens. quem uterque cupiens exercitus obtinere, quia loci oportunitas non parvum benificium confert, dextram partem Hunni cum suis, sinistram Romani et Vesegothae cum auxiliariis occuparunt, relictoque de cacumine eius iugo certamen ineunt. dextrum itaque cornum cum Vesegothis Theoderidus tenebat, sinistrum Aetius cum Romanis, conlocantes in medio Sanguibanum, quem superius rettulimus praefuisse Alanis, providentes cautioni militari, ut eum, de cuius animo minus praesumebant, fidelium turba concluderent. facile namque adsumit pugnandi necessitatem, cui fugiendi inponitur difficultas.

(198) e diverso vero fuit Hunnorum acies ordinata, ut in medio Attila cum suis fortissimis locaretur, sibi potius rex hac ordinatione prospiciens, quatenus inter gentis suae rubor positus ab imminenti periculo redderetur exceptus. cornua vero eius multiplices populi et diversae nationes, quos dicioni suae subdiderat, ambiebant.

(199) inter quos Ostrogotharum praeminebat exercitus Valamire et Theodemire et Videmere germanis ductantibus, ipso etiam rege, cui tunc serviebant, nobilioribus, quia Amalorum generis eos potentia inlustrabat; eratque et Gepidarum agmini innumerabili rex ille famosissimus Ardaricus, qui ob nimiam suam fidelitatem erga Attila eius consiliis intererat. nam perpendes Attila
(197) Os grupos se encontraram, como dissemos, nos campos Cataláunicos. O campo-de-batalha era, porém, um local inclinado, que elevava-se bruscamente até uma colina que se destacava e que ambos exércitos desejavam obter, pois o local conferia um benefício considerável. Com os hunos ocupando o lado direito com os seus homens enquanto os romanos, os visigodos com as tropas auxiliares ocupavam a esquerda, [os exércitos] partiram [de suas posições] e deram início a uma disputa pelo topo. Teodorico ocupava com os visigodos a ala direita e Aécio ocupava a esquerda com os romanos, enquanto no meio, por precaução militar, colocavam Sangibano, que acima mencionamos liderar os alanos; como se presumissem que seu entusiasmo fosse menor e quisessem cercá-lo por uma multidão de homens leais, uma vez que mais facilmente aceita a necessidade de lutar aquele a quem foram impostas dificuldades para a fuga.

(198) A linha de batalha dos hunos, de fato, estava organizada de modo diferente, com Átila e os seus homens valentíssimos posicionados no meio; sendo que com essa organização o rei sobretudo preocupava-se consigo mesmo, à medida que, colocado-se modestamente entre o seu povo, o rei livra-se do perigo iminente. As alas eram compostas, na verdade, por povos e nações que [Átila] havia submetido às suas ordens.

(199) Entre esses se destacavam os ostrogodos, sob a liderança dos irmãos Valamiro, Teodomiro e Vidimiro, ainda mais nobres do que o próprio rei a quem então serviam, pois eram iluminados com o poder do clã dos Amali. Também ali estava, com uma incontável tropa, o famosíssimo rei dos gépidas, Ardarico, que pertencia ao conselho de Átila por conta de sua excessiva lealdade; porquanto Átila, avaliando a sua sagacidade, 
sagacitate sua, eum et Valemerem, Ostrogotharum regem, super ceteros regulos diligetab.

(200) erat namque Valamir secreti tenax, blandus alloqui, dolis gnarus; Ardaricus fide et consilio, ut diximus, clarus. quibus non inmerito contra parentes Vesegothas debuit credere pugnaturis. reliqua autem, si dici fas est, turba regum diversarumque nationum ductores ac si satellites notibus Attilae attendebant, et ubi oculo annuisset, absque aliqua murmuratione cum timore et tremore unusquisque adstabat, aut certe, quod iussus fuerat, exequebatur.

(201) solus Attila rex omnium regum super omnes et pro omnibus sollicitus erat. fit ergo de loci, quem diximus, oportunitate certamen. Attila suos diriget, qui cacumen montis invaderent, sed a Thorismundo et Aetio praevenitur, qui eluctati collis excelsa ut conscenderent, superiores effecti sunt, venientesque Hunnos montis benificium facile turbaverunt. prezava-o, assim como Valamiro, mais do que os outros reizinhos.

(200) Uma vez que Valamiro era um bom guardador de segredos, suave na fala, habilidoso nas trapaças; Ardarico, como já dissemos, era conhecido pela lealdade e sabedoria. Ambos, devia [Átila] crer, não sem razão, lutariam contra seus parentes visigodos. O restante da turba de reis e líderes de diversas nações, se é que é justo chamá-los assim, prestava atenção aos gestos de Átila como se fossem a sua própria escolta; e quando este fazia um sinal com os olhos, cada um deles, sem um murmúrio sequer, ainda que com temor e tremor, apresentava-se e certamente executava o que lhe era ordenado.

(201) Apenas Átila era o rei de todos os reis, acima de todos, e preocupado com todos. Então começou a disputa, à qual nos referimos, pelo local vantajoso. Átila dirige seus homens para que invadam o monte, mas é antecipado por Torismundo e Aécio, que sobem a colina elevada lutando. Estando na posição superior, repeliam com facilidade os hunos, por conta do benefício que o monte lhes dava. 


\section{Comentários ao capítulo 38 (197 - 201)}

O capítulo trata da primeira parte da batalha dos campos Cataláunicos chamados assim por estarem próximos à cidade de Catalaunum (atual Châlons-enChampagne, na França). Na descrição das linhas de batalha, um fato chama a atenção: enquanto os visigodos teriam ocupado a ala direita e os romanos a esquerda no exército liderado por Teodorico e Aécio, os hunos teriam ocupado a posição central no exército de Átila. Jordanes justifica a linha de batalha do exército de Teodorico e Aécio como uma tentativa de impedir a deserção dos alanos, instalados na posição central. No caso do exército liderado por Átila, a posição central dos hunos teria sido fruto de seu desejo de se proteger em meio a seus homens. Embora o primeiro argumento seja razoável, o segundo é completamente descabido. Isso fica claro quando, por exemplo, examinamos as campanhas de Alexandre o Grande. A falange macedônica, justamente por consistir no grupo mais forte, normalmente era posicionada no centro - assim como os hunos no exército de Átila. Além disso, o lider militar posicionar-se junto aos guerreiros do centro como costumava fazer o próprio Alexandre - era normalmente exaltado como um ato de coragem. Por último, os hunos não parecem ter tido propriamente uma “família real”, mas um chefe guerreiro. Isso implica que a posição de Átila entre os hunos era assegurada por sua capacidade de demonstrar, continuamente, que merecia ser seguido; de modo que não faria sentido que ele, por assim dizer, "se escondesse” em meio à sua tropa. É perfeitamente razoável, portanto, que Átila e os hunos tenham ocupado a posição central. Nesse sentido, Jordanes provavelmente está repassando uma informação correta que recebeu acerca da batalha. Parece ser na explicação sobre o acontecido que temos uma intervenção da opinião do autor da Getica. Talvez considerar que a decisão de Átila de se posicionar em meio aos de sua tribo, mesmo que no centro, fosse fruto de sua covardia apenas condizesse com o que Jordanes acreditava acerca do caráter do rei dos hunos; ou talvez tal argumento proviesse não propriamente da crença de Jordanes, mas fosse somente uma tentativa de reforçar para os leitores da Getica que Átila era um covarde; talvez fosse algum tipo de combinação dessas duas possibilidades.

O texto segue com a exaltação dos ostrogodos, parte do exército de Átila (199). De acordo com Jordanes, seus líderes, os irmãos Valamiro, Teodomiro e Vidimiro, seriam “ainda mais nobres do que o próprio rei a quem então serviam” por pertencerem ao clã dos Amali. Valamiro, em particular, teria feito parte do conselho de Átila, assim como o "famosíssimo rei dos gépidas", Ardarico, homem de “excessiva lealdade” e "sagacidade” - note-se as amplificações, grifadas. Esses homens estariam acima dos outros "reizinhos" do exército de Átila.

Cabe, nesse ponto, um comentário tradutório. Lê-se, ao final do passo 199, a seguinte oração: "nam perpendes Attila sagacitate sua, eum et Valemerem, Ostrogotharum regem, super ceteros regulos diligetab.” O trecho foi assim vertido por nós para o Português: “Átila, avaliando a sua sagacidade, prezava-o, assim como Valamiro, mais do que os outros reizinhos". Note-se que o diminutivo, na passagem em discussão, funciona como um redutor da força do item lexical "rei"; dado que um "reizinho”, nesse caso, não é um "rei pequeno”, mas é “menos rei”.

O texto latino dá a entender, parece-nos, que Valamiro e Ardarico estariam incluídos entre os tais "reguli”, "reizinhos”. Isso não seria problemático, não fosse por Jordanes não apenas tê-los exaltado imediatamente antes, como continuar a fazê-lo na sequência do texto; de modo que parece-nos pouco provável que 
desejasse incluí-los no grupo. No passo subsequente, o autor/narrador elogia novamente Valamiro ("um bom guardador de segredos, suave na fala, habilidoso nas trapaças”) e Ardarico (“conhecido pela lealdade e sabedoria”); dando a entender, em seguida, que teria sido por conta de suas qualidades que Átila confiara que ambos lutariam contra os seus parentes visigodos (200); e, por fim, declara que “o restante da turba de reis e líderes de diversas nações, se é que é justo chamá-los assim, prestava atenção aos gestos de Átila como se fossem a sua própria escolta”.

Cremos existir, no original, um problema de composição. Por conta da nossa decisão de procurar manter o aspecto avaliativo do original, todavia, decidimos não “corrigi-lo” - razão pela qual nossa versão preserva a aparente ambiguidade dos status de Valamiro e Ardarico. Independente do caráter desses status, Jordanes faz questão de afirmar: "Apenas Átila era o rei de todos os reis, acima de todos, e preocupado com todos.” (201) - note-se as amplificações.

O capítulo se encerra com a tomada, por parte de Torismundo e Aécio, de uma posição vantajosa no alto de um monte. Vale assinalar a ordem em que os dois nomes são mencionados. O nome do comandante romano, aliás, já havia sido mencionado após o do pai de Torismundo, Teodorico, mas nunca antes: "Teodorico e Aécio construíram uma grande barreira de terra” (195), “Teodorico ocupava com os visigodos a ala direita e Aécio ocupava a esquerda com os romanos” (197). É possível que tal ordem seja uma escolha deliberada do autor, com o fito de insinuar uma hierarquia. 


\section{XXXIX}

(202) Tunc Attila cum videret exercitum causa praecedente turbatum, tali eum ex tempore credidit alloquio confirmandum. 'post victorias tantarum gentium, post orbem, si consistatis, edomitum, ineptum iudicaveram tamquam ignaros rei verbis acuere. quaerat hoc aut novus ductor aut inexpertus exercitus.

(203) nec mihi fas est aliquid vulgare dicere, nec vobis oportet audire. quid autem aliud vos quam bellare consuetum? aut quid viro forti suavius, quam vindicta manu querere? magnum munus a natura animos ultione satiare.

(204) adgrediamur igitur hostem alacres: audaciores sunt semper, qui inferunt bellum. adunatas dispicite dissonas gentes: indicium pavoris est societate defendi. en ante impetum nostrum terroribus iam feruntur, excelsa quaerunt, tumulos capiunt et sera paenitudine in campos monitiones efflagitant. nota vobis sunt quam sint levia Romanorum arma: primo etiam testudineque conectunt. vos confligite perstantibus animis, ut soletis, despicientesque eorum aciem Alanos invadite, in Vesegothas incumbite.

(205) inde nobis cita victoria quaerere. unde se continet bellum. abscisa autem nervis mox membra relabuntur, nec potest stare corpus, cui ossa subtraxeris. consurgant animi, furor solitus intumescat. nunc consili, Hunni, nunc arma depromite: aut vulneratus quis adversarii mortem reposcat aut inlaesus hostium clade satietur.

\section{Capítulo 39}

(202) Então Átila, quando viu o seu exército repelido por conta do ocorrido, acreditou que o devesse motivar com um discurso extemporâneo: "Se ficais de pé após vitórias sobre tantas tribos, após submeter o mundo, considero tolice estimular-vos com palavras, como se fosseis líderes novatos ou um exército inexperiente.

(203) Tampouco é justo que eu vos diga algo comum ou conveniente que escuteis algo assim. Aliás, o que, além de guerrear, é vosso costume? Ou o que é mais agradável, para um homem valente, do que buscar a vingança com as [próprias] mãos? É uma dádiva da natureza saciar a alma com a vingança.

(204) Ataquemos com entusiasmo, então, o inimigo; os mais ousados são sempre os que tomam a iniciativa na guerra. Prestai atenção naquelas tribos dissonantes ajuntadas: o fato de estarem aliadas é um indício de pavor. Eis que antes de nosso ataque já sofrem de terror: buscam [locais] elevados, capturam montículos; arrependendo-se tarde demais, pedem auxílio em campo aberto. Notai o quanto são leves para vós as armas dos romanos. Já de primeira, enquanto eles se juntam em formação de tartaruga, vós permanecereis de pé, como é vosso costume, desprezando-os; e então invadi a linha de batalha e pressionai os alanos em direção aos visigodos!

(205) Busquemos, doravante, uma rápida vitória onde a guerra se resolve, pois logo depois de cortados os nervos os membros se afrouxam e tampouco pode ficar de pé um corpos cujos ossos são retirados. Que se elevem em conjunto os [vossos] ânimos e que a [vossa] fúria costumeira engrandeça-se! Agora é hora da sabedoria, ó hunos. Mostrai as [vossas] armas! Que o ferido exija a morte do adversário e que o ileso se satisfaça 
(206) victuros nulla tela conveniunt, morituros et in otio fata praecipitant. postremos cur fortuna Hunnos tot gentium victores adseret, nisi ad certaminis huis gaudia praeparasset? quis denique Meotidarum iter maiores nostros aperuit tot saeculis clausum secretum? quis adhuc inermibus cedere faciebat armatos? faciem Hunnorum non poterat ferre adunata collectio. non fallor eventu: hic campus est, quem nobis tot prospera promiserunt. primus in hoste tela coiciam. si quis potuerit Attila pugnante otio ferre, sepultus est'. his verbis accensi, in pugna cuncti praecipitantur. através da destruição do inimigo!

(206) Nenhum dardo atinge os que hão de vencer e os que hão de morrer mesmo no ócio caem diante do Destino. Por fim, por que a Fortuna colocaria os hunos vitoriosos sobre tantas tribos, a não ser que estivesse a prepará-los para a alegria da presente disputa? Quem mais teria aberto o caminho através do [pântano] Meotis ${ }^{18}$, fechado e secreto por tantos séculos, aos nossos ancestrais? Quem, ainda, teria feito homens armados caírem diante de desarmados? Uma coleção ajuntada [de homens] não pode fazer frente aos hunos. Não estou enganado sobre o que acontece: este é o campo que nos foi prometido por tantos triunfos. Serei o primeiro a atirar o dardo no inimigo. Se alguém puder ficar parado enquanto Átila luta, [já] está sepultado.” Inflamados por essas palavras, em conjunto lançaram-se à luta.

\footnotetext{
18 “Palus Maeotis” era o nome genérico aplicado às terras pantanosas próximas à foz do rio Tanais (atual Don, na Rússia).
} 


\section{Comentários ao capítulo 39 (202 - 206)}

O capítulo consiste em um discurso motivacional de Átila, proferido, segundo Jordanes, por conta da posição de desvantagem de seu exército. Nada no discurso parece verdadeiro, a começar pela sua extensão: duzentas e trinta e oito palavras no texto latino. É concebível que o rei dos hunos houvesse proferido algumas palavras de ordem ou ditado alguns comandos, se não às tropas em si, aos "reizinhos" encarregados de partes dela. Mais do que isso não nos parece que teria sido possível, ao menos no calor da batalha. Como no caso das epístolas do capítulo 36, o discurso de Átila talvez não seja muito mais do que um dispositivo literário. Além disso, o que é dito, em si, parece ir pouco além do lugar-comum: o rei dos hunos minimiza a tomada do monte pelo inimigo, associando isso à falta de coragem para o enfrentamento; depois exalta as virtudes guerreiras dos próprios homens e promete execução a quem desertar.

De tudo o que teria sido dito por Átila, cabe destacar a seguinte passagem: "Prestai atenção naquelas tribos dissonantes ajuntadas: o fato de estarem aliadas é um indício de pavor”. O exército de Átila também é composto por diversas tribos, o que provavelmente significa que ele estaria dirigindo-se não a todos, mas apenas aos hunos. Além disso, o trecho em questão ressalta as diferenças entre romanos (com seus auxiliares de diversas origens), visigodos e alanos. "Dissonantes”, aí, pode tanto ser uma referência às diferentes línguas faladas pelos referidos povos, como também pode significar que eles não combinam entre si. Nossa tradução mantém a ambiguidade do original - no qual lê-se "adunatas dispicite dissonas gentes" - por conta da nossa decisão de procurar manter o seu aspecto avaliativo. 


\section{$X L$}

(207) Et quam vis haberent res ipse formidinem, praesentia tamen regis cunctatione merentibus auferebat. manu manibus congrediuntur; bellum atrox multiplex immane pertinax, cui simile nulla usquam narrat antiquitas, ubi talia gesta referantur, ut nihil esset, quod in vita sua conspicere potuisset egregius, qui huius miraculi privaretur aspectu.

(208) nam si senioribus credere fas est, rivulus memorati campi humili ripa praelabens, peremptorum vulneribus sanguine multo provectus est, non auctus imbridus, ut solebat, sed liquore concitatus insolito torrens factus est cruoris augmento. et quos illic coegit in aridam sitim vulnus inflictum, fluenta mixta clade traxerunt: ita constricti sorte miserabili sorvebant putantes sanguinem quem fuderant sauciati.

(209) hic Theodoridus rex dum adhortans discurrit exercitum, equo depulsus pedibusque suorum conculcatus vitam maturae senectutis conclusit. alii vero dicunt eum interfectum telo Andagis de parte Ostrogotharum, qui tunc Attilanis sequebantur regimen. hoc fuit, quod Attilae praesagio aruspices prius dixerant, quamvis ille de Aetio suspicaret.

(210) tunc Vesegothae dividentes se ab Alanis invadunt Hunnorum caterva et pene Attilam trucidarent, nisi providus prius fugisset et se suosque ilico intra septa castrorum, quam plaustris

\section{Capítulo 40}

(207) Ainda que a violência trouxesse ela própria o horror, a presença do rei propiciava aos merecedores a cessação da hesitação. Os homens encontravam-se frente-a-frente; [trata-se de] uma guerra atroz, complexa, desumana e contínua - diferente de todas as batalhas que os tempos antigos relatam. Conta-se que ali ocorreram feitos tais que [mesmo] um homem de posição, em [toda] a sua vida, não poderia ver coisa alguma que se assemelhasse a essas façanhas.

(208) Pois, se é justo crermos nos mais velhos, um riachuelo que corre pela parte baixa do referido campo transbordou com o sangue dos ferimentos dos mortos. Não cresceu com a chuva, como costumava, mas teve suas águas agitadas e tornadas uma torrente incomum por conta do acréscimo de sangue. E aqueles que ali se reuniam, com uma árida sede resultante dos ferimentos recebidos, extraíram [do riachuelo] um fluido misturado com carnificina: e assim, compelidos por uma sorte miserável, sorviam o sangue derramado pelos feridos.

(209) Ali o rei Teodorico, que cavalgava apressado encorajando o exército, foi atirado pelo [próprio] cavalo e pisoteado pelos pés dos seus [homens], terminando a vida em uma idade bastante avançada. Outros dizem que, na verdade, foi morto pelo dardo de Andag, do grupo dos ostrogodos, que então seguiam o comando de Átila. Foi isso o que os adivinhos disseram a Átila anteriormente na predição, ainda que ele tenha suspeitado que se tratava de Aécio.

(210) Então os visigodos, separando-se dos alanos, invadem um bando de hunos e quase trucidavam Átila, não fosse ele ter fugido antes, preparado que estava, e ter imediatamente reaberto, com os seus [homens], o portão que 
vallatum habebat, reclusisset: quamvis fragili munimine, eo tamen quaesierunt subsidium vitae. quibus paulo ante nullus poterat muralis agger obsistere.

(211) Thorismund autem regis Theodoridi filius, qui cum Aetio collem anticipans hostes de superiore loco proturbaverat, credens se ad agmina propria pervenire, nocte caeca ad hostium carpenta ignarus incurrit. quem fortiter demicante quidam capite vulnerato equo deiecit, suorumque providentia liberatus a proeliandi intentione desivit.

(212) Aetius vero similiter noctis confusione divisus cum inter hostes medius vagaretur, trepidus, ne quid incidisset adversi Gothos, inquiret, tandemque ad socia castra perveniens, relicuum ${ }^{19}$ noctis scutorum defensione transegit. postera die luce orta cum tumulatos cadaveribus campos aspicerent nec audere Hunnos erumpere, suam arbitrantes victoriam scientesque Attilam non nisi magna clade confossum bella confugere, cum tamen nil ageret vel prostratus abiectum, sed strepens armis, tubis canebat incursionemque minabatur, velut leo venabulis praessus ${ }^{20}$ speluncae aditus obambulans nec audet insurgere nec desinet fremetibus vicina terrere: sic bellicosissimus rex victores suos turbabat inclusus. conduzia ao acampamento, que era cercado por carroças. Ainda que [o local] fosse fragilmente fortificado, buscaram ali um subsídio à sobrevivência aqueles que, pouco antes, não poderiam ser contidos nem por muralhas de terra.

(211) Enquanto isso, o filho do rei Teodorico, Torismundo, que com Aécio antecipou-se na tomada da colina e, desse local elevado, repeliu os inimigos, crente de que voltava para junto das próprias tropas, por conta da noite cega, chegou desavisado às carruagens dos inimigos. Enquanto brigava valentemente, foi ferido na cabeça e retirado do cavalo. Foi liberado [depois], por conta da precaução de seus homens, e desistiu da intenção de combater.

(212) Aécio, na verdade, também vagou em meio aos inimigos, por causa da confusão da noite, separado de seus homens. Temendo que algo de ruim houvesse acontecido aos [visi]godos, procurou-os até que finalmente chegou ao acampamento aliado, atravessando o restante da noite protegido por escudos. Quando a luz surgiu no dia seguinte, [os romanos], vendo os campos transformados em um cemitério, cheio de cadáveres que estavam, e tampouco ouvindo os hunos despontarem, avaliaram que haviam sido vencedores; e sabiam que um Átila ferido não fugiria da guerra a não ser por conta de uma grande carnificina. Este, ainda que estivesse abatido, não fazia qualquer coisa baixa; pelo contrário, fazia barulho com as armas, soava as trombetas e ameaçava uma investida. Era como um leão ferido, preso em uma caverna, que caminha até a entrada e não ousa investir, mas que não deixa de aterrorizar as cercanias com rugidos. Assim, também, [este] rei belicosíssimo agitava aqueles que o haviam derrotado.

\footnotetext{
19 “Relicuum” em vez de "reliquum”.

20 "Praessus" em vez de "prehensus".
} 
(213) conveniunt itaque Gothi Romanique et quid agerent de superato Attila, deliberant. placet eum obsidione fatigari, quia annonae copiam non habebat, quando ab ipsorum sagittariis intra septa castrorum locatis crebris ictibus arceretur accessus. fertur autem desperatis rebus praedictum regem adhuc et suppraemo magnanimem equinis sellis construxisse pyram seseque, si adversarii inrumperent, flammis inicere voluisse, ne aut aliquis eius vulnere laetaretur aut in potestate hostium tantarum gentium dominus perveniret.
(213) Então godos e romanos reunem-se e deliberam sobre o que fazer com o derrotado Átila. Gostariam de esgotá-lo com um cerco, pois ele não possuía muitas provisões, e porque os próprios arqueiros, posicionados dentro do portão que conduzia ao acampamento, impediam o acesso com repetidas flechadas. Foi dito, ainda, que o rei, ainda que a situação fosse desesperadora, suportou-a e que, com suprema coragem, mandou que construíssem para si uma pira com as selas de cavalos - para que, caso os adversários invadissem [o acampamento], nenhum deles tivesse a alegria de feri-lo ou que o senhor de tantas tribos ficasse em poder do inimigo. 


\section{Comentários ao capítulo 40 (207 - 213)}

Jordanes inicia o capítulo destacando o caráter especial do conflito: “[tratase de] uma guerra atroz, complexa, desumana e contínua - diferente de todas as batalhas que os tempos antigos relatam" (207). O autor da Getica, depois disso, conta-nos sobre um riachuelo que corria pela parte baixa dos campos Cataláunicos e que teria transbordado com o sangue dos mortos e feridos (208).

No passo subsequente, o autor/narrador nos oferece duas versões sobre a morte de Teodorico: ele teria caído do cavalo e então sido pisoteado pelos próprios homens ou sido atingido por um dardo arremessado pelo ostrogodo Andag (209). Mais importante do que a causa mortis do rei dos visigodos, porém, é o que Jordanes nos conta em seguida: a predição dos adivinhos de Átila havia se concretizado; ainda que o rei dos hunos houvesse pensado que ela se referia a Aécio. O “condutor supremo do inimigo”, como se pode ler no passo 196, teria sido na verdade Teodorico. Devemos entender com isso que, na campanha em questão, a posição de Aécio - e, por extensão, a dos romanos - teria sido subalterna. Teriam sido os visigodos, ademais, a quase "trucidarem” Átila (210). O rei dos hunos teria escapado por pouco e fugido para o seu acampamento cercado de carroças.

Na continuação da narrativa, temos uma confusão trazida pela noite. Tanto Torismundo (211) quanto Aécio (212) teriam se perdido e vagado em meio aos inimigos. O primeiro teria ido até as carruagens dos inimigos e "enquanto brigava valentemente", teria sido ferido, derrubado do cavalo, mas finalmente salvo por seus homens. O segundo, nos conta Jordanes, teria também vagado sem rumo em meio aos inimigos, "por causa da confusão da noite”. Aécio acabaria encontrando o acampamento dos visigodos, onde seria acolhido. O autor da Getica nos explica, nesse ponto, que o comandante romano havia saído em busca dos dos visigodos por estar preocupado que algo de ruim lhes houvesse acontecido. Em outras palavras, devemos acreditar que o apreço de Aécio pelos visigodos teria sido grande a ponto de ele arriscar a própria vida saindo em sua procura numa vagueação cega no meio da noite.

Visigodos e romanos teriam encontrado os campos cobertos de cadáveres ao raiar do dia, sendo que o exército de Átila estaria recolhido em seu acampamento (212). Este era defendido a flechadas, de modo que um ataque direto não teria sido possível. Acuado, o rei dos hunos teria mandado construir uma pira com as selas dos cavalos, "para que, caso os adversários invadissem [o acampamento], nenhum deles tivesse a alegria de feri-lo ou que o senhor de tantas tribos ficasse em poder do inimigo" - um ato não apenas corajoso mas de "suprema coragem” segundo Jordanes (213). 
$X L I$

(214) Verum inter has obsidionum moras Vesegothae regem, fili patrem requirunt, admirantes eius absentiam. dum felicitas fuerit subsecuta. cumque diutius exploratum ut viris fortibus mos est. inter densissima cadavera repperissent, cantibus honoratum inimicis spectantibus abstulerunt. videres Gothorum globos dissonis vocibus confragosos adhuc inter bella furentia funeri reddidisse culturam. fundebantur lacrimae, sed quae viris fortibus inpendi solent. nam mors erat, sed Hunno teste gloriosa, unde hostium putaretur inclinatam fore superbiam, quando tanti regis efferri cadaver cum suis insignibus conspiciebant.

(215) at Gothi Theodorito adhuc iusta solventes armis insonantibus regiam deferunt maiestatem fortissimusque Thorismud bene gloriosos manes carissimi patris, ut decebat filium, patris exequias prosecutus. quod postquam peractum est, orbitatis dolore commotus et virtutis impetu, qua valebat, dum in reliquis Hunnorum mortem patris vindicare contendit, Aetium patricium ac si seniorem prudentiaeque maturum de hac parte consuluit, quid sibi esset in tempore faciendum.

(216) ille vero metuens, ne Hunnis funditus interemptis a Gothis Romanum praemeretur imperium, praebet hac suasione consilium, ut ad sedes proprias remearet regnumque, quod pater reliquerat, arriperet, ne germani eius opibus adsumptis pater-

\section{Capítulo 41}

(214) $\mathrm{Na}$ verdade, enquanto o cerco demorava, os visigidos foram procurar o [seu] rei e o filho o [seu] pai, surpresos que estavam com a sua ausência quando o sucesso foi conseguido. Depois de uma longa busca, contudo, encontraram-no em meio a muitos cadáveres, como costuma acontecer com os homens valentes, e removeram-no entoando cantos em sua honra enquanto os inimigos observavam. Podia-se ver, ainda, grupos irregulares de godos, com suas vozes dissonantes, retornando para a preparação do funeral ainda que a guerra furiosa continuasse. Eram derramadas lágrimas, mas aquelas que costumam derramar os homens valentes. Tratava-se, pois, da morte, mas de uma gloriosa, como podiam atestar os hunos; uma morte através da qual - se podia pensar - a soberba do inimigo se reduziria quando tantos observassem o cadaver do rei ser carregado com suas insígnias.

(215) Os godos, quando ainda tratavam dos justos [ritos] para Teodorico, ao fazerem soar suas armas, concederam a régia majestade; e o valentíssimo Torismundo bem acompanhou os gloriosos manes e as exéquias do caríssimo pai, como era apropriado a um filho. Depois disso ter sido feito, comovido pela dor da orfandade e também pelo ímpeto da virtude, a qual não lhe faltava, [Torismundo] busca vingar-se pela morte do pai contra os hunos remanescentes e consulta o patrício Aécio, mais velho e mais experiente do que si, acerca do que seria hora de se fazer.

(216) Este, temendo na verdade que, se os hunos fossem completamente destruídos, o Império Romano seria pressionado pelos godos, aconselha [Torismundo] através do [seguinte] argumento: que retornasse ao seu local de residência e se apoderasse do reino deixado pelo pai ou, 
nis Vesegotharum regno pervaderent graviterque dehinc cum suis et, quod peius est, miseriterque pugnaret. quo responsum non ambiguae, ut datum est, sed pro sua potius utilitate susceptum relictis Hunnis redit ad Gallias.

(217) sic humana fragilitas dum suspicionibus occurrit, magna plerumque agenda rerum occasione intercepit. in hoc etenim famosissimo et fortissimarum gentium bello ad utrisque partibus CLXV milia caesa referuntur, exceptis quindecim milibus Gepidarum et Francorum, qui ante congressionem publicam noctu sibi occurrentes mutuis concidere vulneribus, Francis pro Romanorum, Gepidas pro Hunnorum parte pugnantibus.

(218) Attila igitur cognita discessione Gothorum, quod de inopinatis collegi solet, inimicorum magis aestimans dolum diutius se intra castra continuit. sed ubi hostium absentia sunt longa silentia consecuta, erigitur mens ad victoriam, gaudia praesumantur atque potentis regis animus in antiqua fata revertitur. Thorismud ergo, patre mortuo in campis statim Catalaunicis, ubi et pugnaverat, regia maiestate subvectus Tolosam ingreditur. hic licet fratrum et fortium turba gauderet, ipse tamen sic sua initia moderatus est, ut nullius repperiret de regni sucessione certamen. do contrário, seus irmãos receberiam os recursos paternos, ocupando violentamente o reino dos visigodos; de modo que, doravante, ele teria que lutar e, o que é pior, miseravelmente. [Torismundo] aceitou esta resposta não como duvidosa, como ela era, mas em vez disso, tendo em mente o interesse próprio, abandonou os hunos e retornou às Galliae.

(217) Assim, quando a fragilidade humana encontra-se com as suspeitas, ela intercepta a oportunidade para maioria das coisas importantes serem feitas. De fato, nesta famosíssima guerra entre as mais valentes tribos, diz-se que sessenta e cinco mil foram mortos de cada um dos lados, sem contar os quinze mil gépidas e francos, que antes do enfrentamento geral se encontraram à noite e caíram por conta dos ferimentos mutuamente infligidos com os francos lutando a favor dos romanos e os gépidas dos hunos.

(218) Átila, então, quando foi percebida a partida dos godos, concluiu ser algo incomum e, julgando tratar-se de uma trapaça dos inimigos, continuou dentro do acampamento por mais tempo. Quando, porém, a ausência do inimigo foi seguida por um longo silêncio, sua mente excita-se com a vitória, de modo que ele imagina alegrias futuras e seus pensamentos voltam-se para oráculos antigos sobre um poderoso rei. Quanto a Torismundo, com o pai tendo sido morto nos campos Cataláunicos, onde lutara, ingressa em Tolosa portador da régia majestade. Ali era permitido que seus valentes irmãos e a multidão celebrassem, sendo que ele próprio foi tão moderado de início que ninguém procurou disputar a sucessão do reino. 


\section{Comentários ao capítulo 41 (214 - 218)}

Jordanes inicia o capítulo destacando a valentia do rei visigodo morto, Teodorico (200): “encontraram-no em meio a muitos cadáveres, como costuma acontecer com os homens valentes”. Cabe, a essa altura, um comentário tradutório. O original latino traz, na passagem em questão, "viris fortibus", forma dativa de "viri fortes" - literalmente "homens fortes". Ocorre que "fortes", aí, corresponde, em nossa interpretação, figurativamente a "valentes”, "corajosos”. Malgrado esse mesmo sentido conotativo para o adjetivo "forte" ainda aparecer por vezes dicionarizado em Português, causaria-nos grande estranheza a noção de que um guerreiro foi encontrado morto em meio a outros por conta de sua força. Se, todavia, em vez de "força" tivéssemos aí "valentia", tal afirmação faria não nos causaria surpresa alguma, porquanto seria compreensível que um guerreiro valente tivesse morrido lutando. Decidimos, diante do exposto, traduzir "viris fortibus" como "com os homens valentes".

Ato contínuo, o autor da Getica afirma que a morte de Teodorico teria sido não apenas gloriosa, mas também capaz de reduzir a soberba do inimigo. Trata-se de uma afirmação curiosa, porquanto o capítulo anterior traz a informação de que eram duas as versões para a morte do rei dos visigodos (209): teria sido pisoteado pelos seus próprios homens depois de ter caído do cavalo ou atingido por um dardo arremessado pelo ostrogodo Andag. Nenhuma dessas duas versões, de todo modo, parece propícia a uma exaltação da figura do já muito idoso Teodorico. Jordanes resolve tal dificuldade ao postular que a soberba do inimigo teria sido reduzida não pela morte do rei em si, mas pelo espanto do inimigo diante da demonstração de reverência dos visigodos ao falecido rei durante os ritos fúnebres que se seguiram: "uma morte através da qual - se podia pensar - a soberba do inimigo se reduziria quando tantos observassem o cadaver do rei ser carregado com suas insígnias" (214). Talvez seja razoável interpretarmos a passagem em questão como mais um exemplo da grande distância que por vezes parece existir entre o que Jordanes reporta (o rei morreu de um modo aparentemente banal; seu cadáver foi encontrado em meio a outros; ritos fúnebres se seguiram) e como ele interpreta o que reporta (o rei foi valente por não ter fugido do inimigo; os inimigos se espantaram com os ritos fúnebres).

A narrativa prossegue com um elogio a Torismundo, filho de Teodorico e herdeiro do trono dos visigodos. Chamado por Jordanes de "valentíssimo" ("fortissimus", no original), o novo rei, ainda que estivesse motivado "pela dor da orfandade e também pelo ímpeto da virtude" a buscar vingança, teria demonstrado prudência e moderação ao consultar Aécio, mais experiente que si, sobre como proceder após a morte do pai (215). O romano, preocupado com o fortalecimento dos visigodos no caso da destruição completa dos hunos, teria convencido Torismundo, então, a desistir da vingança (216). Jordanes nos revela, dessarte, um aspecto pérfido da política externa romana: o emprego dos povos "bárbaros" uns contra os outros, numa espécie de jogo político-militar em que os romanos sempre podiam mudar de lado. A passagem em questão reforça para o leitor, ademais, o poderio dos visigodos, porquanto os romanos estão dispostos a preservar o seu maior inimigo, Átila, para não terem que correr o risco de enfrentá-los no futuro. 
O capítulo se encerra com um apanhado das baixas na batalha dos campos Cataláunicos e com o retorno de Torismundo à capital dos visigodos, Tolosa (atual Toulouse). Quanto às baixas nessa "famosíssima guerra" ("famosissimum bellum", no original), as estimativas apresentadas por Jordanes, ainda que levemos em conta que o combate possa ter se estendido noite adentro, parecem exageradas: "sessenta e cinco mil foram mortos de cada um dos lados, sem contar os quinze mil gépidas e francos, que antes do enfrentamento geral se encontraram à noite” (217). Números como esses seriam possíveis, embora pouco prováveis, apenas nos séculos anteriores. Diz-se que o imperador Trajano, por exemplo, em ocasião da segunda batalha de Tapae, ocorrida no ano de 101, teria empregado cinquenta mil homens contra as forças de Decébalo, rei da Dacia, e mantido um contingente similar na retaguarda. ${ }^{21}$ Mesmo no caso de batalhas ocorridas no século IV ainda teria sido possível, ao menos em tese, que o número de baixas se aproximasse do relatado por Jordanes na passagem referida. Quando os imperadores Constantino I e Licínio, por exemplo, colocaram frente a frente os exercitos oriental e ocidental, em 324, cada lado teria contado com mais de cem mil soldados. ${ }^{22}$ Os romanos sofriam, todavia, com dificuldades crônicas para realização do recrutamento militar desde pelo menos o último quartel do século IV, de modo que os combates passaram, forçosamente, a envolver um menor número de participantes. Tomemos, a título de exemplo, a que talvez tenha sido a maior batalha envolvendo forças romanas no primeiro quartel do século V, ocorrida em Florentia (atual Florença), no ano 405. Nela, os romanos provavelmente contaram com não mais do que vinte e oito mil soldados contra as forças lideradas pelo godo Radagásio. ${ }^{23}$ Isso nos leva a crer que ou Jordanes estava sendo hiperbólico ao relatar as fatalidades ou recebeu informações exageradas. É concebível, também, que o número real de participantes tenha chegado ao autor da Getica como o número de baixas.

\footnotetext{
${ }^{21}$ Conforme BENNETT (1991, p. 91).

${ }^{22}$ Conforme POHLSANDER (2004, p. 44),

${ }^{23}$ Estimativas nossas, discutidas em pormenor em nossa dissertação de mestrado: SARTIN (2011, pp. 76-81).
} 


\section{$X L I I$}

(219) Attila vero nancta occasione de secessu Vesegotharum, et, quod saepe optaverat, cernens hostium solutione per partes, mox iam securus ad oppressionem Romanorum movit procinctum, primaque adgressione Aquileiensem obsidet civitatem, quae est metropolis Venetiarum, in mucrone vel lingua Atriatici posita sinus, cuius ab oriente murus Natissa amnis fluens a monte Piccis elabitur ${ }^{24}$.

(220) ibique cum diu multumque obsidens nihil paenitus ${ }^{25}$ praevaleret, fortissimis intrinsecus Romanorum militibus resistentibus, exercitu iam murmurante et discedere cupiente, Attila deabumlans circa muros, dum, utrum solveret castra an adhuc remoraretur, deliberat, animadvertit candidas aves, id est ciconias, qui fastigia domorum nidificant, de civitate foetos suos trahere atque contra morem per rura forinsecus conportare.

(221) et ut erat sagacissimus inquisitor, presentit et ad suos: 'respicite', inquit, 'aves futurarum rerum providas perituram relinquere civitatem casurasque arces periculo imminente deserere. non hoc vacuum, non hoc credatur incertum; rebus presciis ${ }^{26}$ consuetudinem mutat ventura formido.' quid plura? animos suorum rursus ad oppugnandam Aquileiam inflammat. qui

\section{Capítulo 42}

(219) Átila, na verdade, por conta da oportunidade que encontrara com a partida dos visigodos, deu-se conta daquilo que frequentemente desejara: de que o inimigo estava dividido. Logo depois disso, já [sentindo-se] seguro, moveu seus armamentos para oprimir os romanos. Como primeira agressão, faz cerco à cidade de Aquileia, cidade principal dos vênetos, [situada] em um cabo ou língua no golfo do Atriaticus, cujo muro oriental é banhado pelo [rio] Natissa, que flui caudaloso do monte Piccis.

(220) E lá, quando o cerco havia durado muitíssimo tempo sem que qualquer [das partes] prevalecesse totalmente - cheios de coragem que estavam, dentro [da cidade], os resistentes soldados romanos - e quando o [seu] exército já estava murmurante e desejoso de partir, Átila, ao caminhar em torno das muralhas deliberando se deveria desfazer o acampamento ou permanecer por mais tempo, viu e ouviu aves brancas - isto é, umas cegonhas que fazem ninhos nos telhados das casas - trazerem seus filhotes da cidade e, ao contrário do que costumam, levá-los para fora, através dos campos.

(221) E, como era um investigador muitíssimo sagaz, teve um pressentimento e disse aos seus [homens]: "Observai as aves, que preveem as coisas futuras, abandonarem a cidade prestes a ser destruída e desertarem refúgios prestes a cair, por conta do perigo iminente. Não credes que isso seja algo vazio ou incerto: o terror pelas coisas vindouras muda o costume de coisas antigas. Para que dizer mais?” Os ânimos dos seus [homens]

\footnotetext{
${ }^{24}$ Como será discutido nos comentários ao capítulo, o texto emendado por Mommsen apresenta "elambit" nessa passagem. Em uma nota de rodapé, porém, o editor menciona a variante textual “elabitur", presente no Codex Vaticanus Ottobonianus 1346, que aqui adotamos.

${ }^{25}$ O texto latino traz uma hipercorreção: "paenitus" em lugar de "penitus".

26 "Presciis" em lugar de "priscis".
} 
machinis constructis omniaque genera tormentorum adhibita, nec mora et invadunt civitatem, spoliant, dividunt vastantque crudeliter, ita ut vix eius vestigia ut appareat reliquerunt.

(222) exhinc iam audaciores et necdum Romanorum sanguine satiati per reliquas Venetum civitates Hunni bacchantur. Mediolanum quoque Liguriae metropolim et quondam regiam urbem pari tenore devastant nec non et Ticinum aequali sorte deiciunt vicinaque loca saevientes allidunt demoliuntque pene totam Italiam. cumque ad Romam animus fuisset eius adtentus accedere, sui eum, ut Priscus istoricus refert, removerunt, non urbi, cui inimici erant, consulentes, sed Alarici quodam Vesegotharum regis obicientes exemplo, veriti regis sui fortunam, quia ille post fractam Romam non diu supervixerit, sed protinus rebus humanis excessit.

(223) igitur dum eius animus ancipiti negotio inter ire et non ire fluctuaret secumque deliberans tardaret, placida ei legatio a Roma advenit. nam Leo papa per se ad eum accedens in agro Venetum Ambuleio, ubi Mincius amnis commeantium frequentatione transitur. qui mox deposuit exercitatu furore et rediens, quo venerat, iter ultra Danubium promissa pace discessit, illud pre $^{27}$ omnibus denuntians atque interminando decernens, graviora se in Italia inlaturum, nisi ad se Honoriam Valentiniani principis germanam, filiam Placidiae Augustae, cum portione sibi regalium opum novamente se inflamam para atacar Aquileia, que constroem máquinas e infligem tormentos de todos os tipos, e sem demora invadem a cidade, saqueiamna, dividem-na [entre si] e devastam-na cruelmente. Deixam-na de tal modo que seus vestígios dificilmente indicariam que algo ali existiu.

(222) A partír de então, os hunos, já mais ousados e ainda não saciados com o sangue dos romanos, enlouquecem percorrendo as outras cidades do Venetum. Também devastam Mediolanum, metrópole da Liguria e outrora cidade imperial, com igual empenho; e arrasam do mesmo modo Ticinum e danificam furiosamente locais vizinhos e quase demolem toda a Italia. Ainda que o ânimo de Átila estivesse voltado para um ataque a Roma, os seus [homens], como relata o historiador Prisco, impediram-no de ir até lá; não por conta da cidade [em si], de quem eram inimigos, mas oferecendo-lhe o exemplo Alarico, outrora rei dos visigodos. Temiam pela sorte de seu [próprio] rei, pois aquele não sobreviveu por muito tempo após despedaçar Roma pelo contrário, de imediato abandonou os assuntos humanos.

(223) Então, enquanto o ânimo de Átila estava dividido na questão, flutuando entre ir e não ir, e ele se demorava ponderando consigo próprio, uma embaixada pacífica vem de Roma; tanto que o próprio papa Leão se reúne com ele no campo Ambuleio, no Venetum, onde o caudaloso [rio] Mincius é frequentemente atravessado pela multidão. [Átila,] logo depois disso, pôs de lado a [sua] fúria cultivada e partiu pelo caminho através do Danubium, através do qual viera, com a paz tendo sido prometida. Fêlo anunciando diante de todos a sua ameaça de que atacaria a Italia de modo ainda mais grave a não ser que lhe enviassem Honória, irmã do imperador

\footnotetext{
27 “Pre” em vez de “prae”.
} 
debita mitterent.

(224) ferebatur enim, quia haec Honoria, dum propter aulae decus ad castitatem teneretur nutu fratris inclusa, clam eunucho misso Attilam invitasse, ut contra fratris potentiam eius patrociniis uteretur: prorsus indignum facinus, ut licentiam libidinis malo publico comparet.
Valentiniano e filha da augusta Placídia, com a parte da riqueza imperial que lhe cabia.

(224) Dizia-se, então, que essa Honória, enquanto mantinha a castidade por conta do decoro da corte e era enclausurada por ordem do irmão, enviara secretamente um eunuco para convocar Átila, de modo que ela pudesse usar a sua proteção contra o poder do irmão certamente um feito indigno, o de conseguir liberdade para a [própria] libido em troca do prejuízo coletivo. 


\section{Comentários ao capítulo 42 (219 - 224)}

Jordanes dá início ao capítulo relatando que a partida dos visigodos teria dado a Átila a confiança necessária para mover suas tropas dos campos Cataláunicos, provavelmente localizados a sudoeste de Catalaunum (atual Chalônsen-Champagne, na França), número 1 no mapa abaixo, e atacar Aquileia (hoje uma comuna no nordeste da Itália), número 9. Trata-se de uma decisão surpreendente, em virtude da derrota ante a coalizão liderada por romanos e visigodos.

Considerando-se as rotas disponíveis na Tabula Peutingeriana, um mapa romano contemporâneo, o exército de Átila provavelmente teria passado pelas adjacências das localidades de Noviomagus (Nijon), Andemantunno (Langres) e Vesontine (Besançon). De lá, teria partido em sentido leste até Brigantio (Bregenz). A marcha teria sequência em sentido sul, até as adjacências de Como. O trecho final consistiria em uma marcha rumo ao leste, passando por Bergomum (Bérgamo) e Verona. Tal itinerário é razoável, ademais, porque teria permitido que as forças de Átila se afastassem dos territórios em que os romanos exerciam um controle mais efetivo e adentrassem regiões mais fronteiriças, como a Raetia. Adicionalmente, se tomarmos por base a Tabula Peutingeriana, tal itinerário consiste no caminho mais curto entre Catalaunum e Aquileia. Trata-se, ainda assim, de um percurso considerável, de quase 1.400 quilômetros, que talvez haja sido percorrido pelos hunos sem que fossem confrontados.

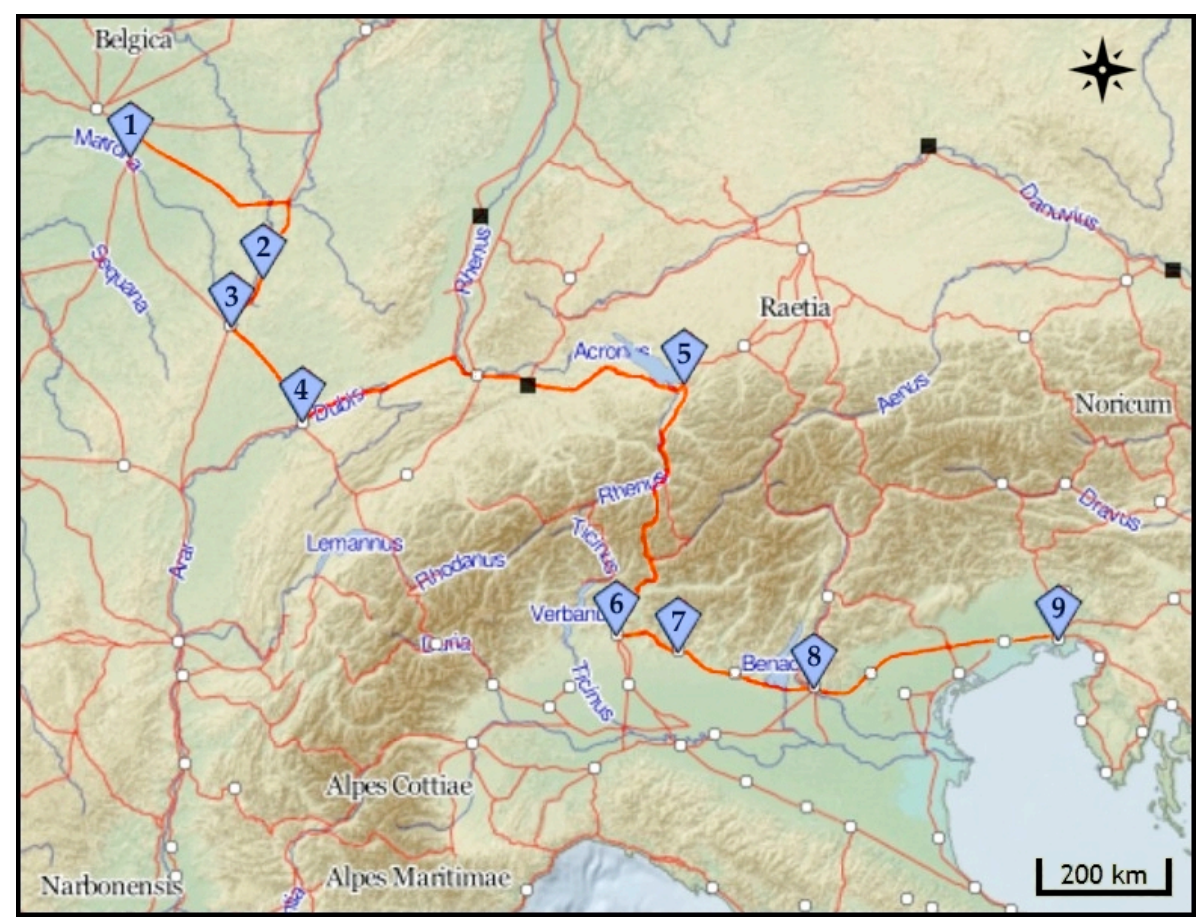

Mapa 1: reconstituição do possível itinerário das forças de Átila após a batalha dos campos Cataláunicos. A sequência teria sido:

[1] Catalaunum (Châlons-en-Champagne) $\rightarrow$ [2] Noviomagus (Nijon) $\rightarrow$ [3] Andemantunno (Langres) $\rightarrow$ [4] Vesontine (Besançon) $\rightarrow$

[5] Brigantio (Bregenz) $\rightarrow$ [6] Como $\rightarrow$ [7] Bergomum (Bérgamo) $\rightarrow$ [8] Verona $\rightarrow$ [9] Aquileia. 
Desde os tempos da república romana, o iustum iter, o dia de marcha normal de uma legião regularmente treinada, era de vinte milhas romanas ou cerca de trinta quilômetros. Segundo Flávio Vegécio, escritor do século V, uma legião que marchasse a passo acelerado poderia percorrer até vinte e quatro milhas romanas em um dia - ou cerca de trinta e seis quilômetros. ${ }^{28}$ É notório, todavia, que os hunos eram exímios cavaleiros. Eles, por outro lado, teriam trazido consigo carroças (vide passo 210). Cremos que não seria absurdo, diante disso, presumirmos que a velocidade de deslocamento "típica" de um exército de hunos fosse comparável à marcha acelerada dos romanos, trinta e seis quilômetros por dia. Isso significa que o percurso de Átila e seu exército de Catalaunum até Aquileia, em viagem ininterrupta, levaria em torno de quarenta dias - tempo suficiente para que os romanos montassem um ataque.

Em certo sentido, essa aparentemente incólume viagem dos hunos poderia servir para nos dar a dimensão da fraqueza das forças romanas. Por outro lado, a ida o exército de Átila para o leste a partir de Vesontine talvez houvesse funcionado como um simulacro de fuga, de modo que os romanos talvez não houvessem visto motivo para acompanhá-los a partir desse ponto. Lembremos do que afirmou Jordanes a respeito de Átila no passo 186: "Sob a excessiva ferocidade, existia um homem astuto, que, antes de fazer guerra, lutava através de artifícios.”

É difícil sabermos, ademais, o quanto dos territórios em questão os romanos efetivamente controlavam a essa altura. A região a norte de Brigantio - a porção norte-oriental da Raetia - provavelmente estava sob controle dos alamanos, aliados dos hunos. É possível, aliás, que a própria cidade de Brigantio estivesse sob o seu controle. Nesse caso, Átila poderia ter pousado tranquilamente na região, de modo a preparar sem pressa seu ataque à Italia. Por outro lado, áreas ao sul de Vesontine, como no entorno dos lagos Lausonius (Léman) e Everdunensis (de Neuchâtel), incluindo as cidades de Genneva (Genebra) e Aventicum Heletiorum (Avenches), provavelmente eram controladas pelos burgúndios - que lutaram contra os hunos na batalha dos campos Cataláunicos (passo 191) e que eram, portanto, aliados dos romanos. Um mapa do Império Romano Ocidental pareceria, a essa altura, uma colcha de retalhos, por conta dos enclaves controlados por chefes guerreiros estrangeiros.

Embora as fontes (quase) contemporâneas que nos restaram não sejam específicas quanto a datas, é provável que a batalha dos campos Cataláunicos tenha ocorrido no verão de 451. Presume-se que Átila tenha atacado Aquileia apenas no início do ano seguinte, por conta de uma menção na crônica de Hidácio de Aquae Flaviae (atual Chaves, em Portugal) de que os hunos saquearam a Italia "no segundo ano do reinado do imperador Marciano" (secundo regni anno principis Marciani $)^{29}$. Parece-nos que a distância entre as duas datas reforça nossa conjectura de que Átila teria pousado tranquilamente em Brigantio junto aos alamanos enquanto preparava o ataque à Italia.

Voltemos, todavia, às questões mais claramente tradutórias, porquanto o texto de Jordanes o exige. Encontramos, no passo 220, uma construção linguística curiosa: "primaque adgressione Aquileiensem obsidet civitatem, quae est metropolis Venetiarum, in mucrone vel lingua Atriatici posita sinus, cuius ab

\footnotetext{
${ }^{28}$ Flavius Renatus Vegetius, De Re Militari, 1.9 (LANG, 1885). Para o iustum iter, vide BENARIO (1986).

${ }^{29}$ Hydatius Lemicensis, Continuatio Chronicum Hieronymianorum, 154 (Mommsen, 1894, p. 26).
} 
oriente murus Natissa amnis fluens a monte Piccis elambit." Embora cause alguma estranheza ver a grafia "Atriaticus” em vez de "Adriaticus”, considerada clássica, os primeiros períodos do excerto são de fácil interpretação: "Como primeira agressão, [Átila] faz cerco à cidade de Aquileia, cidade principal dos vênetos, [situada] em um cabo ou língua no golfo do Atriaticus”. Porém, na continuação, encontramos duas dificuldades tradutórias: uma principal, por conta de "elambit"; e uma secundária, em decorrência de "amnis fluens". Ocorre que o verbo "elambo" não parece estar dicionarizado. "Lambo", todavia, o está e corresponderia ao nosso verbo "lamber”. “Elambere” seria algo como “lamber para fora”, "lamber algo que está fora”.

Do que se trata essa passagem, afinal? Do Natissa, um rio. "Amnis" usualmente tem o sentido de "rio caudaloso", mas aparece aí em função adjetiva. A essa altura do processo de interpretação/tradução, teríamos algo como "cujo muro é 'lambido para fora' a partir do oriente pelo [rio] Natissa, que flui caudaloso do monte Piccis.” Isso não faria muito sentido, é claro, a não ser que o prefixo em “elambit” não significasse “para fora”, mas “por fora”. Teríamos, então: “cujo muro é 'lambido por fora' a partir do oriente pelo [rio] Natissa, que flui caudaloso do monte Piccis.” Isso resolvido, o único problema tradutório restante nesse trecho seria o de substituir o metafórico "lamber por fora" por algo mais usual no Português, como "banhado", correto? Não. Essa tradução talvez fosse inconteste se o verbo principal não estivesse na voz ativa, "elambit”, mas na passiva, "elambitur". Estaria dito, literalmente, que "o muro lambe por/para fora”. Seria então o muro que lambe o rio e não o contrário? É possível. Nesse caso, porém, "Natissa" não poderia estar no caso ablativo, como está, mas no acusativo, "Natissam". O trecho parece-nos gramaticalmente confuso.

Esse imbróglio poderia ser resolvido mais facilmente, é claro, se conhecêssemos bem a geografia da região. Não é o caso. Ocorreu-nos, então, verificar se Mommsen havia registrado alguma variante textual desse trecho em suas notas de rodapé. Segundo o editor, nenhum dos manuscritos apresenta a forma acusativa "Natissam", mas um deles, o Codex Vaticanus Ottobonianus 1346, apresenta "elabitur" (sem o "m”) - uma forma passiva. ${ }^{30}$ A partir disso, alteramos o texto-fonte em prol dessa variante e concluímos que seria o rio a lamber o muro e não o inverso.

Resolvido o problema interpretativo, restava-nos ainda decidir como escrever em Português corrente algo que correspondesse a "o muro é lambido por fora pelo rio". Se interpretássemos a metáfora como um indício de um registro mais poético, seria possível imaginar algo como "o muro é beijado pelo rio". Ocorre, porém, que Jordanes não escreve de forma poética. Seu registro é simples, baixo até. É provável que o verbo "ela[m]bo", em seu dialeto latino, fosse uma palavra usual, com um sentido técnico inclusive, e que seu uso não implicasse em maiores preocupações estilísticas. Diante disso, decidimos interpretar o verbo em questão como "banhar", palavra que usualmente empregaríamos em descrições dessa natureza. Teríamos, então: “cujo muro é banhado a partir do oriente pelo [rio] Natissa, que flui caudaloso do monte Piccis." Tal construção ainda nos causou alguma estranheza, por conta sobretudo de "a partir do oriente". Decidimo-nos, então, por "cujo muro oriental é banhado pelo [rio] Natissa, que flui caudaloso do monte Piccis.” Essa solução é semelhante às adotadas por Charles Mierow, em sua

${ }^{30}$ MOMMSEN (1882, p. 195). 
tradução para o Inglês, e por José María Sánchez Martín, em sua tradução para o Castelhano. Respectivamente, "On the eastern side its walls are washed by the river Natissa, flowing from Mount Piccis." 11 e "cuyas murallas baña el río Natisone, que corre desde el monte Picis" ${ }^{32}$.

No passo seguinte, 221, encontramos outra questão tradutória de interesse: "ibique cum diu multumque obsidens nihil paenitus praevaleret, fortissimis intrinsecus Romanorum militibus resistentibus, exercitu iam murmurante et discedere cupiente...”. Causou-nos dificuldade, em especial, o trecho sublinhado. Não porque seja difícil interpretá-lo, mas por ter sido difícil vertê-lo ao nosso idioma. Vejamos o trecho no seu contexto: "E lá, quando o cerco havia durado muitíssimo tempo sem que qualquer [das partes] prevalecesse totalmente fortissimis intrinsecus Romanorum militibus resistentibus - e quando o [seu] exército já estava murmurante e desejoso de partir...”. “Intrínsecus” aí não é adjetivo, mas advérbio, “do lado de dentro”. Teríamos, então, algo como: “do lado de dentro, os resistentes soldados romanos [estavam] fortíssimos/valentíssimos" note-se a amplificação ao final.

Jordanes tem sido consistente em seu uso de "fortis" com o sentido de "valente”. Parece-nos estranho, porém, chamar de "valentes" soldados que estão protegidos por muralhas, porquanto "valentia" tem um sentido claramente ativo. Como os soldados romanos estavam apenas a se defender, talvez uma palavra pertencente ao mesmo campo semântico de "valentia", mas com o sentido não necessariamente tão ativo fosse uma escolha mais apropriada ao contexto. Pensamos, nesse caso, que "coragem", que tem também o sentido de "firmeza de ânimo”. "Corajosíssimos” talvez fosse uma boa escolha para traduzir "fortissimi”, mas soaria pouco idiomático. Ocorre, ademais, que não temos, no trecho em questão, "fortissimi”, mas o seu ablativo, "fortissimis". Diante disso, "fortissimis" foi por nós traduzido como "cheios de coragem”, de modo que o trecho sublinhado ficou assim: "cheios de coragem que estavam, dentro [da cidade], os resistentes soldados romanos”.

A narrativa continua com Átila,“um investigador muitíssimo sagaz”, interpretando a partida das aves como um presságio de que o cerco a Aquileia será bem sucedido - note-se a amplificação. Depois disso, os homens de Átila, motivados, "sem demora invadem a cidade, saqueiam-na, dividem-na [entre si] e devastam-na cruelmente. Deixam-na de tal modo que seus vestígios dificilmente indicariam que algo ali existiu." (221). Logo a seguir, Jordanes assim escreve: “A partír de então, os hunos, já mais ousados e ainda não saciados com o sangue dos romanos, enlouquecem percorrendo as outras cidades do Venetum.” (222) - note-se a amplificação. O verbo que traduzimos por "enlouquecem” é "bacchantur" flexão de "bacchor". Este, por seu turno, pode tanto significar algo como "realizar um festival em homenagem a Baco", como "agir de modo selvagem, como alguém ébrio em um ritual a Baco". O autor o usa no segundo sentido.

Jordanes reforça, nesse trecho, a imagem dos hunos como um povo violento, cruel e irracional - basicamente o oposto do que seriam os godos. Cala-se, porém, quanto à possível presença de ostrogodos no exército de Átila. Os ostrogodos lutaram sob o seu comando na batalha dos campos Cataláunicos. Não haveria motivo para imaginarmos que nem ao menos uma parte deles continuou a

\footnotetext{
31 JORDANES (1915, p. 112).

32 JORDANES (2001, p. 110).
} 
acompanhá-lo. O próprio Jordanes, mais à frente na narrativa (253), admitirá que os ostrogodos só teriam encontrado oportunidade para se libertarem do domínio dos hunos após a morte de Átila. Ainda assim, ele chama o exército de Átila, certamente multiétnico, de "hunos".

O capítulo se encerra com uma breve menção ao famoso encontro entre Átila e o papa Leão, cujas palavras teriam feito com que o rei dos hunos, então hesitante a respeito de realizar ou não um ataque a Roma, desistisse de tal empreitada. Havendo concordado com a paz, Átila partiria rumo a terras transdanubianas. Antes de fazê-lo, todavia, teria exigido a mão de Honória, a enclausurada irmã do imperador Valentiniano. 
XLIII

(225) Reversus itaque Attila in sedes suas et quasi otii penitens ${ }^{33}$ graviterque ferens a bello cessare, ad Orientis principem Marcianum legatos dirigit, provinciarum testans vastationem, quod sibi promissum a Theodosio quondam imperatore minime persolveretur, et inhumanior solito suis hostibus appareret. haec tamen agens, ut erat versutus et callidus, alibi minatus arma sua commovit, et, quod restabat indignationi, faciem in Vesegothas convertit.

(226) sed non eum, quem de Romanis, reportavit eventum. nam per dissimiles anteriores vias recurrens, Alanorum partem trans flumen Ligeris considentem statuit suae redigere dicioni, quatenus mutata per ipsos belli facie terribilior immineret. igitur ab Dacia et Pannonia provinciis, in quibus tunc Hunni cum diversis subditis nationibus insidebant, egrediens Attila in Alanos movit procinctum.

(227) sed Thorismud rex Vesegotharum, fraudem Attilae non inpari subtilitate presentiens, ad Alanos tota velocitate prius advenit, ibique supervenientis Attilae iam motibus preparatus occurrit, consertoque proelio pene simili eum tenore, ut prius in campos Catalaunicos, ab spe removit victoriae fugatumque a partibus suis sine triumpho remittens in sedes proprias fugire compulit. sic Attila famosus et multarum victoriarum dominus dum quaerit famam perditoris abicere et quod prius a Vesegothis pertulerat abolere, gemi-
Capítulo 43

(225) E assim Átila volta ao seu local de residência e como se estivesse arrependido pela inatividade e sofresse gravemente com o cessar da guerra, envia embaixadores ao imperador [romano] do oriente Marciano, prometendo que devastaria províncias - pois daquilo que certa feita lhe teria sido prometido pelo imperador Teodósio [II] muito pouco haveria sido pago - e que os seus exércitos se mostrariam mais desumanos do que de costume. Sendo versado e calejado, [Átila] conduziu, porém, seus exércitos a outro lugar e, como ainda lhe restava indignação, virou o rosto na direção dos visigodos.

(226) Ele não obteve, porém, o mesmo sucesso que com os romanos. Retornando [às Galliae] por vias diferentes das anteriores, [Átila] decide submeter ao seu comando a parte dos alanos estabelecida além do rio Ligeris (Loire), para através deles mudar o aspecto da guerra e se tornar uma ameaça mais terrível. Assim, partindo das províncias da Dacia e da Pannonia, nas quais os hunos estavam então instalados com diversas tribos submissas, Átila move seus armamentos contra os alanos.

(227) Mas Torismundo, rei dos visigodos, com sutileza sem par pressente a trapaça de Átila. Parte primeiro e a toda velocidade até os alanos. Ali, tendo chegado primeiro, já preparado apressa-se para as movimentações de Átila. Travam combate quase de modo a continuar o ocorrido antes, nos campos Cataláunicos, e [Torismundo] retira [de Átila] a esperança na vitória, pondo em fuga o seu lado sem [qualquer] triunfo, compelindo-o a fugir encolhido para o seu local de residência. Assim Átila, senhor famoso e de muitas vitórias, quando busca reduzir a fama de seu subjugador e por um fim ao

\footnotetext{
33 “Penitens” em vez de “paenitens”.
} 
nata sustenit inglorioususque recessit.

(228) Thorismud vero repulsis ab Alanis Hunnorum catervis sine aliqua suorum lesione Tolosa migravit suorumque quieta pace conposita[.] tertio anno regni egrotans, dum sanguinem tollit de vena, ab Ascalc suo clienti inimico nuntiante arma subtracta peremptus est. una tamen manu, quam liberam habebat, scabillum tenens sanguinis sui extitit ultor, aliquantos indiantes sibi extinguens. que havia tido que suportar da parte dos visigodos, obtém uma segunda [derrota] e retira-se de modo inglório.

(228) Torismundo, em particular, tendo expulsado os hunos das terras dos alanos sem qualquer dano ao próprio bando, partiu com os seus [homens] para Tolosa em quieta e ordenada paz. No terceiro ano de seu reinado, quando lhe tiravam sangue das veias e estava sem armadura, foi morto por seu cliente Ascalco, que trazia notícias sobre o inimigo. Ainda assim, pegando um banquinho com a mão que tinha livre, tornou-se vingador do próprio sangue, matando ele próprio muitos dos conspiradores. 


\section{Comentários ao capítulo 43 (225 - 228)}

O capítulo tem início com Átila de volta ao seu local de residência. Jordanes relata, então, as ameaças do rei dos hunos a Marciano, imperador romano do oriente. Átila estaria disposto a devastar províncias, sendo que "os seus exércitos se mostrariam mais desumanos do que de costume” (225) - note-se a amplificação. Teríamos aí um vilão consciente da própria vilania. Por outro lado, Jordanes nos conta, Átila teria alegado que os romanos orientais não lhe haviam pago o que Teodósio II prometera. O tal Marciano havia chegado ao trono ao desposar Pulquéria, mãe do imperador Teodósio II, que falecera em meados 450 em decorrência de um acidente hípico. Nessa altura da história, estáriamos quiçá em meados de 452.

Chegamos, então, a um dos pontos da narrativa por nós mencionados na seção introdutória: o "versado e calejado” Átila teria ameaçado Marciano, mas teria por objetivo atacar não o Império Romano do Oriente, mas os visigodos nas Galliae. O exército do rei dos hunos teria partido, então, da Dacia e da Pannonia rumo a uma área "além do Ligeris (Loire)" (leia-se "ao norte”), para primeiro submeter o grupo de alanos que lutou ao lado de romanos e visigodos na batalha dos campos Cataláunicos. Jordanes ressalta, ademais, que o percurso até as Galliae, dessa vez, foi diferente do anterior.

A imprecisão dessas informações dificulta, obviamente, um bom entendimento acerca do deslocamento das tropas. Primeiramente, Dacia e Pannonia são duas regiões de grande extensão. Além disso, o termo "Dacia" ou "Dacia Traiana", originalmente remetia a terras ao norte do rio Danubium, correspondentes aproximadamente à Romênia atual. A região foi abandonada pelos romanos ainda no terceiro quartel do século III, de modo que teria sido perfeitamente possível que Átila tivesse ali o seu "local de residência” (sedes), a sua capital. Os colonos da evacuada Dacia Traiana foram instalados pelo imperador Aureliano no que então era a Moesia Superior, que passou a ser chamada “Dacia Aureliana”, com capital em Serdica (atual Sófia, na Bulgária). Não é provável, todavia, que Jordanes estivesse a referir-se à Dacia Aureliana, visto que essa região, muito mais ao sul, provavelmente ainda estava sob controle romano. Além disso, a Dacia Traiana fazia fronteira com a Pannonia. Esta corresponderia, grosso modo, à porção da Hungria atual situada a oeste do Danúbio.

Pareceu-nos, a princípio, que seria mais provável que o tal local de residência de Átila se situasse em terras transdanubianas, na Dacia Traiana. Por outro lado, não parece provável que homens estacionados na Pannonia rumassem primeiro para o leste, com o fito de reunirem-se ao restante do exército de Átila, digamos, em Napoca (atual Cluj, na Romênia), e então para o oés-noroeste, de modo a passar não por Brigantio (Bregenz), como no deslocamento anterior, mas por algum caminho situado ao norte dos Alpes. Além disso, na Tabula Peutingeriana, não há ligação direta entre a Dacia Traiana e a Pannonia a não ser pelo sul. Isso torna o cenário acima ainda menos provável. Parece-nos muito mais razoável, assim, a suposição de que Átila não estivesse instalado no que seria, strictu sensu, seu local de residência, sua “capital”, mas na Pannonia, talvez em alguma cidade romana fronteiriça capturada, e houvesse recebido reforços do leste, da Dacia Traiana. 
Na sequência dos acontecimentos, Torismundo, rei dos visigodos, "com uma sutileza sem par" - note-se a amplificação - teria se antecipado a Átila e chegado aos alanos antes dele, impondo-lhe derrotas sucessivas e pondo "em fuga o seu lado sem [qualquer] triunfo" (227). Depois disso, o heroico rei dos visigodos partiu para Tolosa “em quieta e ordenada paz” (228) - note-se a amplificação.

\section{Resumo dos capítulos 44, 45, 46 e 47 (229 - 245)}

Como os capítulos mencionados no título acima não contêm passagens referentes a Átila, decidimos não inclui-los no presente trabalho. Cabe, contudo, uma breve explicação acerca de seu conteúdo.

Jordanes discorre sobre reinado de Teodorico II, irmão e sucessor de Torismundo, ocorrido entre os anos 453 e 466 (passos 229 a 234) e então prossegue com os eventos ocorridos quando Eurico o sucedeu no trono dos visigodos, entre os anos 466 e 484 (passos 235 a 240). Fá-lo, todavia, sem mencionar o fratricídio que conduziu Eurico ao trono. Tal assassinato, porém, não foi ignorado por autores como Hidácio de Aquae Flaviae, que o menciona em sua crônica (cuja última entrada refere-se ao ano de 468), e por Isidoro de Hispalis (atual Sevilha, na Espanha), que a ele se refere em sua Historia de regibus Gothorum, Vandalorum et Suevorum (escrita por volta de 624). ${ }^{34}$ Cabe que tenhamos em mente, a essa altura, que Átila, que também assassinou o irmão para ter o monopólio do poder político, não recebeu de Jordanes o mesmo benefício que Eurico (passo 181).

Ato contínuo, Jordanes aborda o destino do Império Romano do Ocidente entre a morte de Valentiniano III, em 455, e a deposição de Rômulo Augústulo por Odoacro, em 476 (passos 241 a 243). Após tratar brevemente do governo de Odoacro, Jordanes relata a ascensão ao trono daquele que seria o último rei dos visigodos, Alarico II, no ano de 485 (244 a 245). O que autor da Getica o considere “o último" se justifica porque o reino dos visigodos nas Galliae foi basicamente tomado pelos francos liderados por Clóvis em 507, na batalha dos campos Vogladenses (hoje Vouillé, na França), e só iria ressurgir na Hispania décadas mais tarde, após a composição da Getica.

Depois disso, o fluxo narrativo é interrompido e Jordanes recua para a segunda metade do século IV, com o fito de relatar o que teria se passado com os ostrogodos desde sua separação dos visigodos. Na parte final do longo capítulo 48, Átila reaparece na narrativa, de modo que retomamos a tradução no ponto imediatamente anterior.

\footnotetext{
${ }^{34}$ Hydatius Lemicensis, Continuatio Chronicum Hieronymianorum, 156 (Mommsen, 1894, p. 27); Isidorus Hispalensis, Historia de regibus Gothorum, Vandalorum et Suevorum, 33 (Migne, 1862, col. 1066).
} 


\section{XLVIII}

\section{[...]}

(252) Sed nobis, ut ordo, quem coepimus, decurrat, ad Vandalarii sobulem $^{35}$, quae trino flore pululabat, redeundum est. hic enim Vandalarius, fratuelis Hermanaric et supra scripti Thorismundi consubrinus ${ }^{36}$, tribus editis liberis in gente Amala gloriatus est, id est Valamir Thiudimir Vidimir. ex quibus per successione parentum Valamir in regno conscendit adhuc Hunnis eos inter alias gentes generaliter optinentibus.

(253) eratque tunc in tribus his germanis contemplatio grata, quando mirabilis Thiudimer pro fratris Valamir militabat imperio, Valamir vero pro altero iubebat ornando, Vidimer servire fratribus aestimabat. sic eis mutua affectione se tuentibus nulli paenitus deerat regnum, quod utrique in sua pace tenebant. ita tamen, ut saepe dictum est, imperabant, ut ipsi Attilae Hunnorum regis imperio deservirent: quibus nec contra parentes Vesegothas licuisset recusare certamen, se necessitas domini, etiam parricidium si iubet, implendum est. nec aliter ab Hunnorum dominio divelli, potuit gens aliqua Scythica, nisi optata cunctis nationibus in commune et Romanis mors Attilae proveniret, quae tam fui vilis, ut vita mirabilis.

\section{Capítulo 48}

\section{[...]}

(252) Mas para que nossa [história] decorra, como a começamos, em ordem, retornemos ao ramo de Vandalário, do qual brotou uma tríplice flor. Esse Vandalário, assim, sobrinho-bisneto de Hermanarico e primo do supramencionado Torismundo, foi louvado por ter gerado três filhos dentro do clã dos Amali: Valamiro, Teodomiro e Vidimiro. Desses, Valamiro sucedeu parentes, ascendendo ao trono ainda no tempo em que os hunos prevaleciam sobre eles e sobre os vários clãs em geral.

(253) E era, àquela época, agradável observar os três irmãos: Teodomiro lutava em prol do reinado do irmão Valamiro; este, por outro lado, ordenava que o primeiro recebesse honrarias; enquanto Vidimiro tinha estima pelo serviço aos irmãos. Assim, eles se protegiam através da afeição mútua e ninguém estava completamente desprovido de um reino, pois ambos (Valamiro e Teodomiro) em paz mantinham-no. Ainda assim, como frequentemente é dito, governavam como se servissem ao reinado do próprio Átila, rei dos hunos, de modo que não lhes foi permitido recusar a disputa contra os seus parentes visigodos - se o [seu] senhor, por necessidade, lhes ordenasse que matassem um parente, isso seria cumprido. Tampouco qualquer outro clã cita pôde libertar-se do domínio dos hunos, a não ser quando sobreveio a morte de Átila, desejada em comum pelos romanos e por todas as nações, a qual foi tão sem valor quanto a sua vida foi admirável.

\footnotetext{
35 "Sobulem" em vez de "subolem".

36 “Consubrinus" em vez de "consobrinus".
} 


\section{Comentários ao capítulo 48 (252 - 253)}

O início do capítulo trata de sucessões ao trono dos ostrogodos. Retomamos a tradução no passo 252, ponto em que Valamiro, mencionado explicitamente nos passos 199 e 200, ascende ao trono, provavelmente na segunda metade da década de 440 .

Jordanes prossegue ressaltando a concórdia entre os irmãos ostrogodos Valamiro, Teodomiro e Vidimiro, o que pode ser contraposto claramente às “trapaças” às quais Átila teria recorrido para tomar o poder do irmão, Bleda (passo 181). Lembremos, ademais, que a Getica não menciona que o rei visigodo Eurico somente ascendeu ao trono ao assassinar o irmão, Teodorico II, em 466.

Antes que o capítulo se encerre com o prenúncio da morte de Átila, Jordanes faz uma defesa da honradez dos três irmãos ostrogodos: "governavam como se servissem ao reinado do próprio Átila, rei dos hunos, de modo que não lhes foi permitido recusar a disputa contra os seus parentes visigodos - se o [seu] senhor, por necessidade, lhes ordenasse que matassem um parente, isso seria cumprido" (253). 
$X L I X$

(254) Qui, ut Priscus istoricus refert, exitus sui tempore puellam Ildico nomine decoram valde sibi in matrimonio post innumerabiles uxores, ut mos erat gentis illius, socians eiusque in nuptiis hilaritate nimia resolutus, vino somnoque gravatus resupinus iaceret, redundans sanguis, qui ei solite de naribus effluebat, dum consuetis ${ }^{37}$ meatibus impeditur, itinere ferali faucibus illapsus extinxit. ita glorioso per bella regi temulentia pudendos exitos dedit. sequenti vero luce cum magna pars diei fuisset exempta, ministri regii triste aliquid suspicantes post clamores maximos fores effringunt inveniuntque Attilae sine ullo vulnere necem sanguinis effusione peractam puellamque demisso vultu sub velamine lacrimantem.

(255) tunc, ut gentis illius mos est, crinium parte truncata informes facies cavis turpavere vulneribus, ut proeliator eximius no femineis lamentationibus et lacrimis, sed sanguine lugeretur virile. de quo id accessit mirabile, ut Marciano principe Orientis de tam feroci hoste sollicito in somnis divinitas adsistens arcum Attilae in eadem nocte fractum ostenderet, quasi quod gens ipsa eo telo multum praesumat. hoc Priscus istoricus vera se dicit adtestatione probare. nam in tantum
Capítulo 49

(254) Na época de sua morte, como relata o historiador Prisco, [Átila] desposou uma moça de extrema elegância, depois de haver tido incontáveis esposas, como era costume em sua tribo. Durante a festa da noite de núpcias, entregou-se excessivamente à farra e ao deitar-se de barriga para cima, pesado que estava por conta do vinho e do sono, um excesso de sangue, que normalmente lhe sairia pelo nariz, fica impedido de escorrer pelos meios usuais e desce perigosamente pelo caminho da garganta, matando-o. Assim, a bebedeira pôs um fim vergonhoso a um rei glorioso por conta das guerras. $\mathrm{Na}$ verdade, quando a maior parte do período iluminado do dia seguinte havia se passado, os serviçais reais, suspeitando de algo infeliz, depois de muito gritarem [à porta], invadem [a câmara real] e encontram Átila morto pelo escoamento de sangue, sem qualquer ferimento, e a moça com o rosto abaixado, coberto por um véu, chorando.

(255) Então, como é costume naquela tribo, arrancada parte do escalpo, [sua] face disforme foi mutilada com feridas escavadas, para que um combatente exímio não fosse pranteado com lamentações e lágrimas efeminadas, mas com sangue viril. A esse respeito ocorreu algo extraordinário, porquanto Marciano, imperador do Oriente, preocupado com um inimigo tão feroz, é assistido em um sonho por uma divindade que lhe mostra, naquela mesma noite, o arco de Átila partido - a arma de arremesso preferida da tribo dos

\footnotetext{
37 Jordanes emprega “consuo" (costurar) em lugar de "consuesco” (costumar). As formas, na segunda pessoa do singular do futuro ativo do indicativo são "consuetis" e "consuesces", respectivamente. A rigor, contudo, talvez fizesse mais sentido se usar o particípio presente de “conscuesco" e colocá-lo no ablativo plural, combinando com "meatibus". Assim, teríamos “consuescentibus meatibus” ou "pelos meios usuais” - que parece ser justamente a ideia que Jordanes tenta transmitir.
} 
magnis imperiis Attila terribilis habitus est, ut eius mortem in locum ${ }^{38}$ muneris superna regnantibus iudicarent.

(256) cuius manes quibus a sua gente honoratae sunt, pauca de multis dicere non omittamus. in mediis si quidem campis et intra tenturia siri$\mathrm{ca}^{39}$ cadavere conlocato spectaculum admirandum et sollemniter exhibetur. nam de tota gente Hunnorum lectissimi equites in eo loco, quo erat positus, in modum circensium cursibus ambientes, facta eius cantu funereo tali ordine referebant.

(257) 'praecipuus Hunnorum rex Attila, patre genitus Mundzuco, fortissimarum gentium dominus, qui inaudita ante se potentia solus Scythica et Germanica regna possedit nec non utraque Romani urbis imperia captis civitatibus terruit et, ne praedae reliqua subderentur, placatus praecibus annum vectigal accepit: cumque haec omnia proventu felicitatis egerit, non vulnere hostim, non fraude suorum, sed gente incolume inter gaudia laetus sine sensu doloris occubuit. quis ergo hunc exitum putet, quem nullus aestimat vindicandum?'

(258) postquam talibus lamentis est defletus, stravam super tumulum eius quam appelant ipsi ingenti commessatione $^{40}$ concelebrant, et contraria invicem sibi copulantes luctu funereo mixto gaudio explicabant, noctuque secreto cadaver terra reconditum copercula primum auro, secundum argentum, tertium ferri hunos. Isso o historiador Prisco diz comprovar através de um testemunho verídico. Átila costumara ser tão terrível para os grandes impérios que os seres superiores anunciaram in loco a sua morte aos governantes.

(256) Não deixemos de dizer ao menos um pouco do muito que a sua tribo fez para honrar o seu espírito. Seu cadáver foi, de fato, colocado no meio de um campo e dentro de uma tenda de seda, como um espetáculo para a admiração, e exibido solenemente; porquanto os melhores cavaleiros de toda a tribo dos hunos cavalgavam em círculos ao redor do local onde ele fora posto, relatando em um canto fúnebre os seus feitos, desta maneira:

(257) “[Eis] o proeminente rei dos hunos Átila, filho de Mundzuco, senhor da mais valente das tribos, que com poderes desconhecidos antes de si possuiu sozinho os reinos da Scythia e da Germania e que também aterrorizou ambos impérios dos romanos através da captura de cidades e, para que não saqueasse as restantes, aceitou aquietar-se ao preço de um tributo anual; e tendo realizado tudo isso, como resultado de seu sucesso, caiu não por um ferimento causado pelo inimigo, tampouco pela trapaça de seus [homens], mas feliz e sem dor em meio às alegrias de sua tribo incólume. Quem, então, pode considerar isso uma morte, quando ninguém considera que é necessário vingá-la?”

(258) Depois que tais lamentos foram exauridos, celebram a "strava", como eles próprios chamam uma grande farra na qual se unem para exibir, alternadamente, o pranto fúnebre e a alegria. Então, no segredo da noite escondem o cadáver sob a terra, sendo os caixões primeiro reforçados com o ouro, depois com a prata e em terceiro com a rigidez do ferro; dando a

\footnotetext{
38 "In locum" em vez de "in loco".

39 "Sirica" em vez de "serica".

40 "Commessatione” em vez de "comissationem".
} 
rigores communiunt, significantes tali argumento potentissimo regi omnia convenisse: ferrum, quod gentes edomuit. aurum et argentum, quod ornatum rei publicae utriusque acceperit. addunt arma hostium caedibus adquisita, faleras vario gemmaro fulgore praetiosas et diversi generis insignia, quibus colitur aulicum decus. et ut tantis divitiis humana curiositas arceretur, operi deputatos detestabili mercede trucidarunt, emersitque momentanea mors sepelientibus cum sepultu. entender, com o seguinte argumento, que todas essas coisas convinham ao rei poderosíssimo: ferro, porque ele submeteu as tribos; ouro e prata, porque aceitou honrarias de ambos impérios. Adicionam armas tomadas dos inimigos caídos, jaezes resplandecentes com várias gemas e insígnias de diversos tipos, com as quais se adornava a corte. E, para que tamanhas riquezas fossem protegidas da curiosidade humana, trucidaram os encarregados desse trabalho, um pagamento abominável; e [assim] a morte súbita chegou tanto para os enterradores como para o sepultado. 


\section{Comentários ao capítulo 49 (254 - 258)}

Jordanes inicia o capítulo com a descrição da morte de Átila, após uma bebedeira na noite de núpcias. O imperador do oriente Marciano, nessa mesma noite, teria tido um sonho no qual o arco do rei dos hunos se partia. O autor da Getica, então, parece temporariamente abandonar o seu monoteísmo e comenta: “Átila costumara ser tão terrível para os grandes impérios que os seres superiores anunciaram in loco a sua morte aos governantes” (255) - note-se as amplificações.

A narrativa prossegue com o funeral do rei dos hunos, que inclui o que é basicamente um discurso lamentoso disfarçado de canto fúnebre. Haveria alguma pessoa bilíngue no funeral de Átila tomando notas sobre o que era dito? Muito provavelmente não. Como é comum no caso dos discursos na historiografia antiga, esse também é conjectural e responde sobretudo à pergunta "O que teria sido dito naquelas circunstâncias?” Em outras palavras, trata-se de um dispositivo literário, elaborado a partir do que R. G. Collingwood chamava "imaginação histórica". É possível que as palavras de louvor a Átila tenham provindo do relato de Prisco, que Jordanes parece tomar como base para muitas das passagens relativas ao rei dos hunos. Mesmo que esse seja o caso, todavia, o autor da Getica escolheu usá-las, de modo que podem ser analisadas quanto à avaliatividade: "[Eis] o proeminente rei dos hunos Átila, filho de Mundzuco, senhor da mais valente das tribos, que com poderes desconhecidos antes de si possuiu sozinho os reinos da Scythia e da Germania e que também aterrorizou ambos impérios dos romanos através da captura de cidades e, para que não saqueasse as restantes, aceitou aquietar-se ao preço de um tributo anual; e tendo realizado tudo isso, como resultado de seu sucesso, caiu não por um ferimento causado pelo inimigo, tampouco pela trapaça de seus [homens], mas feliz e sem dor em meio às alegrias de sua tribo incólume. Quem, então, pode considerar isso uma morte, quando ninguém considera que é necessário vingá-la?” (257) - note-se as muitas amplificações.

O capítulo se encerra com o sepultamento do cadáver do "rei poderosíssimo" (258), coberto por riquezas e em local secreto. Jordanes, até então, enfatizava não apenas o poderio de Átila mas também o seu viés perverso, contrapondo não apenas Átila aos reis godos mas também, por extensão, os hunos e os godos. Na morte de Átila, porém, a ênfase recai mormente sobre o seu poderio. 


\section{Considerações finais}

Átila está presente em doze dos sessenta capítulos da Getica. É notável que o autor de uma história dos godos tenha se detido tanto sobre um bárbaro de outra origem. Jordanes, todavia, parece fazer de Átila um modelo do bárbaro digno de ser temido pelos romanos. Além de poderoso, o rei dos hunos é apresentado como violento, trapaceiro, vingativo e de uma ambição sem limites. Mesmo a sua valentia é relativizada - lembremos, por exemplo, de que Jordanes atribui a decisão de Átila de iniciar a batalha dos campos Cataláunicos no meio da tarde ao receio da derrota, resultante da predição de adivinhos (passo 196).

Quando levamos em conta, todavia, que a Getica teria tido por propósito a valorização dos godos perante uma audiência romano-oriental, compreenderemos que as figuras de Átila em particular e dos hunos em geral foram construídas literariamente como uma espécie de contraponto àqueles. Jordanes, assim, apresenta à sua audiência um grande vilão e o seu bando de malfeitores, ao mesmo tempo em que faz questão de enfatizar o caráter heroico dos visigodos e que procura minimizar a presença dos ostrogodos entre as forças sob o comando do rei dos hunos - lembremos, por exemplo, de como o ataque a Italia pelo exército multiétnico de Átila, que muito provavelmente ainda incluía os ostrogodos àquela altura, é mencionado como tendo sido obra de "hunos” (222).

Quando escreveu a Getica, provavelmente na segunda metade da década de 540, Jordanes supunha que o reino dos visigodos havia chegado ao fim após sua derrota para os francos em 507. Ele não tinha como prever que os visigodos, após mais de meio século de caos, acabariam por estabelecer um novo reino na Hispania, que se estabilizaria sobretudo a partir do reinado de Leovigildo (569 - 586). A guerra de reconquista da Italia pelos romanos orientais, na década de 540, dá-se contra os ostrogodos. A Getica é uma intervenção no debate político que envolve esse conflito. Seu fito parece ser o de valorizar os ostrogodos, a essa altura quase derrotados, para uma audiência romano-oriental. Que tenham sido os visigodos os grandes algozes de Átila ou que os ostrogodos da década de 540 descendam daqueles que lutaram ao lado do rei dos hunos um século antes pouco parece importar. Os méritos dos primeiros podem ser transferidos para os segundos, ao mesmo tempo em que os erros destes podem ser minimizados e racionalizados. A Getica é mais do que uma história, é uma peça política.

Tradução e comentários de:

Gustavo H. S. S. Sartin ghsartin@gmail.com Doutorando em História, Universidade Federal de Ouro Preto

Fonte: Mommsen, Theodorus (ed). Iordanis Romana et Getica. Berolini: Apud Weidmannos: 1882. Monumenta Germaniae Historia. Autorum Antiquissimorum Tomi V Pars Prior. 


\section{Referências bibliográficas}

BenARIO, Herbert W. "Legionary Speed of March before the Battle with Boudicca”. Britannia. v. 17, pp. 358-362, 1986. Society for the Promotion of Roman Studies.

Bennetr, Julian. Trajan Optimus Princeps: A Life and Times. London and New York: Routledge, 1997.

Glare, P. G. W. (ed.). Oxford Latin Dictionary. Oxford: Clarendon Press, 1968.

Goffart, Walter. The Narrators of Barbarian History (550 - 800). Jordanes, Gregory of Tours, Bede, Paul the Deacon. Princeton: Princeton University Press, 1988.

Gordon, C. D. The Age of Attila: Fifth-Century Byzantium and the Barbarians. Ann Arbor: University of Michigan Press, 1961.

JORDANES. Origen y gestas de los godos. Edicción y traducción de José María Sánchez Martín. Madrid: Ediciones Cátedra, 2001.

. The Gothic History of Jordanes in English version, with an Introduction and a Commentary by Charles Christopher Mierow. Princeton and Oxford: Princeton University Press, Humphrey Milford e Oxford University Press, 1915.

LANG, Carolus (ed.). Flavii Vegetii Renati Epitoma Rei Militaris. Stuttgart \& Leipzig: Teubner, 1885.

LÖFSTEDT, Einar. Late Latin. Oslo: Aschehoug \& Co. W. Nygaard, 1959.

MARTIN, J. R.; ROSE, D. Working with Discourse: meaning beyond the clause. London and New York: Continuum, 2007. 2nd. edition.

Migne, Jacques-Paul (ed.). S. Georgii Florentini Gregorii Turonensis Episcopi Opera Omnia necnon Fredegarii Scholastici Epitome et Chronicum cum suis continuatoribus et aliis antiquis monumentis. Parisi: 1849. Patrologia Latina, v. 071.

. (ed.). Sancti Isidori, Hispalensis Episcopi, Opera Omnia, Romae Anno Domini MDCCXCVII Excusa, Recensente Faustino Arevalo. Tomus Quintus. Parisi: 1862. Patrologia Latina, v. 083.

. (ed.). Sanctorum Hilari, Simplicii, Felicis III, Romanorum Pontificum, necnon Victoris Vitensis, Sidonii Apollinaris et Gennadii Presbyteri Massiliensis. Parisi: 1847. Patrologia Latina, v. 058.

Mommsen, Theodorus (ed.). Chronica Minora Saec. IV. V. VI. VII. Volumen II. Berolini: Apud Weidmannos, 1894. Monumenta Germinae Historia. Autorum Antiquissimorum Tomus XI.

. (ed.). Iordanis Romana et Getica. Berolini: Apud Weidmannos: 1882. Monumenta Germaniae Historia. Autorum Antiquissimorum Tomi V Pars Prior.

PARKes, M. B. Pause and Effect: An Introduction to the History of Punctuation in the West. Berkeley and Los Angeles: University of California Press, 1993.

Pohlsander, Hans A. The Emperor Constantine. London and New York: Routledge, 2004.

SAenger, Paul. Spaces Between Words: The Origins of Silent Reading. Stanford: Stanford University Press, 1997.

Saraiva, F. R. dos Santos. Novíssimo Dicionário Latino-Português, Etimológico, Histórico, Geográfico, Mitológico, Biográfico, etc. Rio de Janeiro e Belo 
Horizonte: Livraria Garnier, 2000. 12a. edição.

Sartin, Gustavo H. S. S. As Estruturas Sociais e Econômicas do Império Romano do Ocidente e o Estabelecimento do Reino dos Visigodos nas Galliae Aquitania e Narbonensis. Programa de Pós-Graduação em História da Universidade Federal do Rio Grande do Norte, 2011. Dissertação de Mestrado.

SouZA, Ladjane Farias de. A tradução de termos de recentes desenvolvimentos da Linguística Sistêmico-Funcional para o português brasileiro. Tradução \& Comunicação: Revista Brasileira de Tradutores, no. 22, 2011, pp. 73-90. Anhanguera Educacional Ltda. 